\title{
Students home alone-profiles of internal and external conditions associated with mathematics learning from home
}

\author{
Sarah I. Hofer ${ }^{1}$ D $\cdot$ Frank Reinhold ${ }^{2} \cdot$ Marco Koch $^{3}$
}

Received: 28 April 2021 / Revised: 29 November 2021 / Accepted: 30 November 2021 /

Published online: 5 January 2022

(C) The Author(s) 2022

\begin{abstract}
s
This study aims at describing differences in internal and external resources of students to handle mathematics learning from home. Based on data from $N=2237$ th-grade secondary school students gathered via an online survey at the end of the first school year during the COVID-19 pandemic, we used latent profile analysis to identify student profiles defined by the internal factors perceived value and success of students' math learning from home and the external factors family support and teacher support-all specifically related to home learning. A number of general learning conditions, comprising internal (e.g., sustained attention) and external factors (e.g., socioeconomic status), are included as outcome variables. The best-fitting four-profile solution suggests one profile with comparably unfavorable internal and external resources. About $35 \%$ of the students are assigned to that profile. The other three profiles show combinations of, relative to the sample, more and less promising specific home learning and general learning conditions suggesting that these students have different resources available in the face of learning mathematics from home.
\end{abstract}

Keywords Home schooling · Profile analysis · Motivation · Socioeconomic status · Mathematics education · COVID-19

\section{Introduction}

The data for this study was collected during the COVID-19 pandemic in the summer of 2020. Schools closed globally for several weeks. Although learning for school at home is an integral part of many educational systems, having the whole student body of countries all around the world learn half of the time or even only at home for a prolonged time is a situation unparalleled in modern history. Factors associated with learning from home become visible in these times more than ever before - as seen through a magnifying glass.

Sarah I. Hofer

sarah.hofer@gess.ethz.ch

1 ETH Zurich, Weinbergstrasse 43, 8092 Zurich, Switzerland

2 Institute for Mathematics Education, University of Education Freiburg, Freiburg, Germany

3 Individual Differences \& Psychodiagnostics, Saarland University, Saarbrücken, Germany 
The data gathered in this exceptional time can inform us about internal and external conditions of more or less successful learning at home, which is of high relevance, even beyond the current crisis.

On a superordinate level, the success of instruction at school can be expected to depend on two factors: supply (the available learning opportunities) and use (whether and to what extent a student makes use of the learning opportunities provided). The corresponding model is often referred to as the Supply-Use-Model (Brühwiler \& Blatchford, 2011; Helmke \& Weinert, 1997). Figure 1 shows an adapted version of this model. The variables used in this study are embedded into this model and highlighted in color. In addition to the distinction of variables in the existing model, we differentiate between specific home learning conditions (printed in green), comprising variables that very specifically relate to the conditions of learning from home, and general learning conditions (printed in orange), comprising variables that have consistently been found to be associated with learning on a more general level. Our adapted Supply-Use-Model can hence be used as a guiding framework to embed and connect relevant variables describing how different students make use

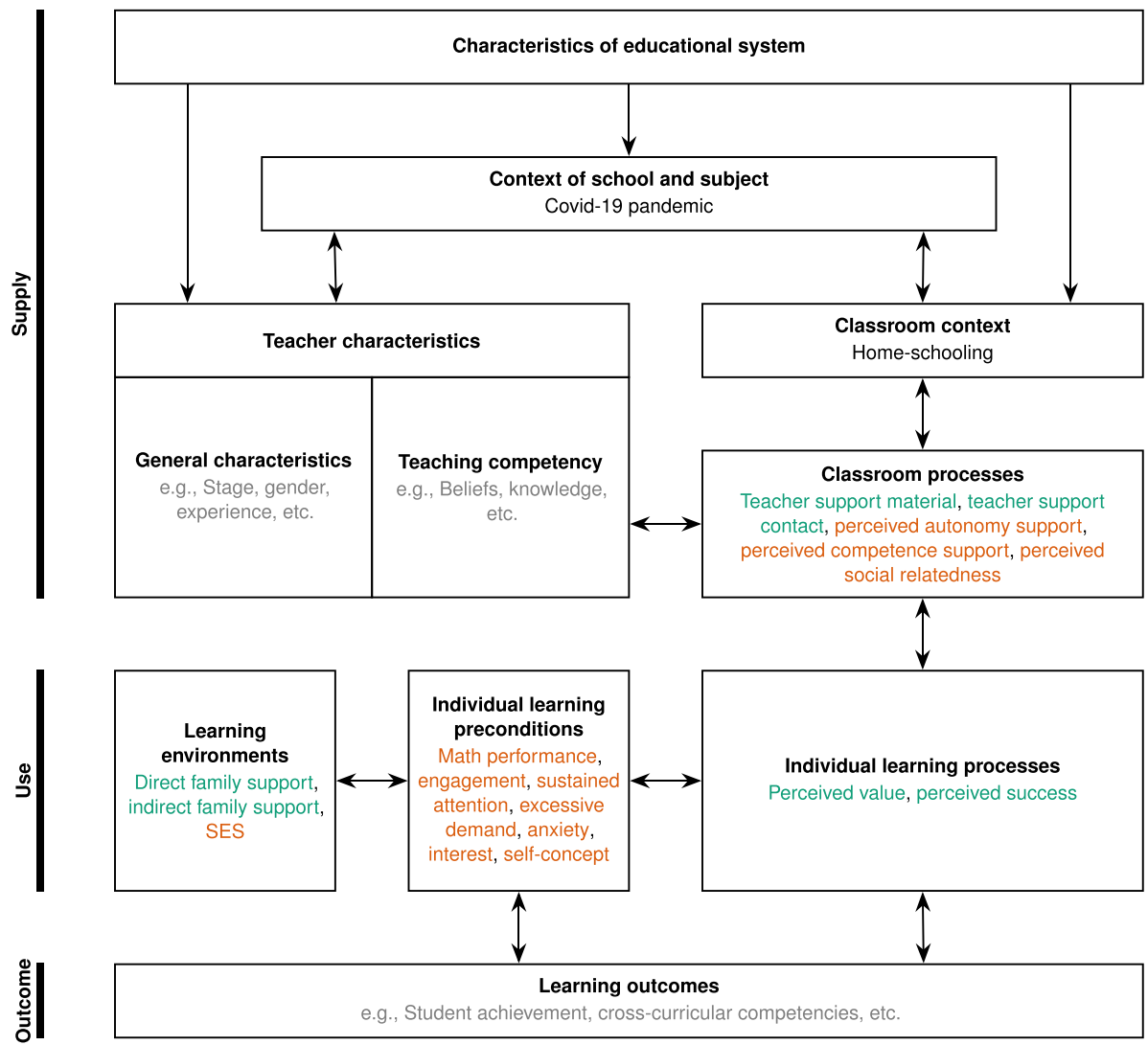

Fig. 1 Adapted Supply-Use-Model based on Brühwiler and Blatchford (2011). Variables used in this study are printed in green (specific home learning conditions) and orange (general learning conditions). The internal factors implemented in this study are represented by "individual learning preconditions" and "individual learning processes," whereas external factors are represented by "classroom processes" and "learning environments." 
of different learning opportunities taking into account the exceptional situation of learning from home during the COVID-19 pandemic.

To investigate potential effects of school closure and learning from home due to the COVID-19 pandemic, Schult et al. (2021) compared the 2020 cohort (school closure) of German fifth-graders to the cohorts of 2017-2019 (regular classroom practice). They could show a decrease in math competencies for the two lowest quartiles of students regarding socio-cultural capital for the 2020 cohort-yet, an increase for the highest quartile. In a comparable study by Engzell et al. (2021), estimations for learning losses due to the pandemic situation were higher for children within the lowest two tertiles in terms of their parents' educational level than for children in the highest tertile. These comprehensive studies underline the risk of certain groups of students to suffer considerably from school closure and learning from home during the pandemic. However, existing research on that topic so far did not apply a person-centered approach that allows analyzing systematically occurring combinations of variables (i.e., internal and external conditions) to describe different student profiles of internal and external resources to handle learning from home. A nuanced description of students' resources for learning from home can inform specific interventions and follow-up research.

Accordingly, in this study, we aim at identifying profiles characterized by students' perceived success and value of learning from home and their families' as well as their teachers' support during this time (specific home learning conditions; see Fig. 1). In order to get an idea of potential explanatory variables, we relate these profiles that are based on internal and external factors directly associated with the specific conditions for learning from home to more general learning conditions such as the student's cognitive and motivational-affective prerequisites and the family's socioeconomic status (SES; Fig. 1). Both within specific home learning conditions and general learning conditions, we hence distinguish between internal and external factors that are expected to contribute to students' success in learning mathematics from home. While internal factors relate to students' attitudes and underlying motivational, affective, and cognitive prerequisites, external factors are located outside the student and refer to supportive (or obstructive) conditions provided by their teachers and families.

Because of considerable differences in teaching, learning, and motivational and emotional orientations towards different school subjects, we focus on mathematics as one core subject in this study. Mathematics proficiency is essential for educational success in different subjects and can be conceived of as a gatekeeper to many career paths (Jones, 2014; Stone et al., 2008). Yet, quite consistently over the last decade, about $20 \%$ of the 15 -yearolds in the PISA survey fail to achieve the minimum mathematical proficiency that is considered a prerequisite for full participation in society (National Center for Education Statistics 2017; OECD, 2016, 2019). Therefore, it is of specific interest to identify students that should be considered at risk to lose ground when learning mathematics from home.

Among the specific home learning conditions, teacher support during learning from home may be one important external factor influencing how well students handle remote schooling. There is already evidence that the guidance and structure provided by teachers outside the regular school context varies considerably (Eickelmann \& Drossel, 2020; Ortiz, 2020). In addition to teachers' provision of material and guidance during remote learning, the home learning environment-i.e., external support from the students' social environment - might, in parts, compensate for the lack of structure and assistance during remote schooling (Coley et al., 2020). Factors internal to the student have to be considered as well when describing resources available in the face of learning mathematics from home. Students' motivation to make use of remote learning opportunities can be conceived of as the 
value students attach to learning math from home and its perceived success (Eccles \& Wigfield, 2002; Eccles et al., 1983; Vroom, 1964).

These internal and external factors that directly reflect students' experiences during remote schooling (specific home learning conditions) can be connected to more general internal and external conditions related to mathematics instruction and learning (general learning conditions). Among those conditions are internal factors such as students' engagement or interest, and self-concept regarding mathematics (e.g., Broadbent, 2017; Broadbent \& Poon, 2015; Fischer et al., 2020), as well as the family's SES (e.g., Coley et al., 2020). In the next sections, we provide further details on the specific home learning conditions and general learning conditions considered in this study to investigate systematic differences in the resources that are available to the students when learning mathematics from home.

\section{Specific home learning conditions}

\section{Internal factors: expectancy and value}

According to expectancy-value theory (Eccles \& Wigfield, 2002; Eccles et al., 1983; Vroom, 1964), domain-specific subjective task value-Do I want to do it? —and perceived success-Can I do it?-explain the motivation to engage in an activity, i.e., the energy and attention directed towards a task. The result of a student's contemplation of these two questions regarding remote schooling can be expected to influence the success of their endeavor to learn from home. This theory offers a widely accepted theoretical foundation for explaining students' motivation to engage in learning-following the overarching idea that students' achievement motivation, perseverance, and choice of tasks are directly related to their expectations of success and the subjective value they assign to the task (e.g., Kosovich et al., 2017). In the context of learning mathematics from home, we understand subjective task value as students' perceived value of continuing studying mathematics even when schools are closed and making use of the learning opportunities provided by their teachers, i.e., video lectures, digital or non-digital learning tasks, or other educational material to build up new or deepen already existing mathematical knowledge. Expectation of success indicates how students anticipate and evaluate their success in learning mathematics from home. Both aspects can be expected to represent seminal drivers of students' motivation to keep learning during the pandemic situation, in particular, since they have been closely linked to successful self-regulated learning (Artino \& Stephens, 2006; Bergey et al., 2018; Panadero \& Alonso Tapia, 2014).

\section{External factors: family and teacher support when learning from home}

While the link between family environment and school success is well-documented for regular school contexts (Elliott \& Bachman, 2018; Foster et al., 2005; Froiland, 2021; Müller \& Ehmke 2013), it can be assumed that aspects such as parental support in doing homework (Almutairi, 2021; Gonida \& Cortina, 2014; Zady \& Portes, 2001) and having a distraction-free workplace at one's disposal (Baticulon et al., 2021; Soria et al., 2020) may increase in relevance when shifting from in-school mathematics learning to learning mathematics from home (see also Köller et al., 2020). Data gathered during the COVID-19 lockdown in England (Andrew et al., 2020) shows that access to resources such as computers and a dedicated study place at home is positively associated with learning time. Access 
to IT infrastructure might be more or less seminal for successful remote schooling depending on the teachers' reliance on digital resources. A safe place to study, however, can be considered a universal precondition for efficient learning from home.

In addition, we know for some time now that there is a strong link between teacher behavior and students' engagement and learning during regular classroom instruction (e.g., Hiebert \& Grouws, 2007; Skinner \& Belmont, 1993). During remote schooling and online teaching, there is evidence for considerable differences in the quality and quantity of learning activities initiated by teachers (e.g., Lohr et al., 2021; Wößmann et al., 2020). Based on data from three German-speaking countries collected during the COVID-19 pandemic, Huber and Helm (2020) emphasize the role of teaching quality during remote schooling over and above home resources. Establishing or maintaining close contact including regular and timely feedback seems to be particularly important to help students learn on their own (Bansak \& Starr, 2021; Hofer et al., 2021; Köller et al., 2020). Providing material and structures (close contact) that allow students to continue learning mathematics while school is closed can be regarded as a crucial resource.

\section{General learning conditions}

\section{Internal factors: cognitive, motivational, and affective prerequisites}

In the following section, we briefly introduce central cognitive (sustained attention and mathematics performance) and motivational-affective factors (engagement, excessive demand, anxiety, self-concept, and interest) that can be expected to play a role in mathematics learning from home. To start with, sustained attention is a cognitive process that allows learners to persistently focus on a task and maintain effort over extended periods of time (Blotenberg \& Schmidt-Atzert, 2019). Learning involves complex processing of information that requires sustained attention (Oakes et al., 2002; Schweizer \& Moosbrugger, 2004). In line with this argument, sustained attention has been shown to be related to school grades in mathematics and German (Steinmayr et al., 2010) and, in particular, to homework completion (Axelrod et al., 2009; Bryan et al., 2001). To manage working for school at home, students have to stay on-task and resist distractions. Sustained attention can hence be considered an important prerequisite for learning mathematics from homewhich demands higher self-regulation skills from the students than regular classroom instruction to maintain engagement (e.g., Broadbent, 2017; Broadbent \& Poon, 2015; Fischer et al., 2020). As a second cognitive factor, we consider domain-specific prior knowledge as one of the strongest predictors of learning in general (e.g., Dochy, 1994; Maguire et al., 1999; Schwartz et al., 2007), as well as in learning secondary school mathematics (Reinhold et al., 2020a; b). Prior knowledge in mathematics can therefore be expected to play an important role in the context of learning mathematics from home as well.

Besides these cognitive prerequisites, the mathematics-related motivational and affective orientations introduced in the following represent individual learning preconditions closely associated with academic performance (Reinhold et al., 2021; Hannula et al., 2016). Accordingly, students' engagement is an established predictor of academic outcomes-also in mathematics (Appleton et al., 2006; Barkatsas et al., 2009; Fung et al., 2018; Skinner et al., 2008). For the purpose of this study, we focus on cognitive engagement (i.e., whether deep learning strategies and adequate cognitive strategies for comprehension are used) and behavioral engagement (i.e., involvement and active participation in classroom and learning activities; Fredricks \& McColskey, 2012; Fredricks et al., 2004). How students affectively 
react to instruction - the "emotional quality of children's involvement in initiating and carrying out learning activities" (Skinner \& Belmont, 1993, p. 572)—can further influence academic performance and learning (Fredricks et al., 2004). If students feel overwhelmed during instruction (i.e., experience excessive demand), their negative evaluations of their own capacity to handle the learning situation might result in lower motivation and engagement, which is in line with expectancy-value theory of achievement motivation (Eccles et al., 1983; Wigfield \& Eccles, 2000). Mathematics anxiety (i.e., feeling concerned when working on mathematics problems; Richardson \& Suinn, 1972) has a well-documented negative relation to mathematics learning and achievement (Ashcraft \& Moore, 2009; Dowker et al., 2016; Hembree, 1990; Ma, 1999)—while mathematics-related self-concept (i.e., students perception about their own mathematical competence; Marsh et al., 2012) is positively related to learning and achievement (Köller et al., 2006; Marsh \& Martin, 2011; Möller et al., 2011). Finally, interest in mathematics (i.e., a positive arousal when dealing with mathematics contents) has been shown to increase students' motivation to engage in mathematics (Pekrun et al., 2006) and to support learning processes (Hidi \& Renninger, 2006).

\section{External factors: family SES and general teacher support (not pandemic-specific)}

Studies focusing on effects of the family SES on learning often analyze consequences of the summer break and inquire after family investments in learning and relate it all to differences in SES. To start with, although there is no agreement on its actual size, research suggests a decline in achievement over the summer break (or, alternatively, at least a flattening of the gain) which is more pronounced for mathematics than for reading. There is evidence for a stronger summer break effect for lower SES as compared to upper SES students (Alexander et al., 2001; Cooper et al., 1996; Quinn et al., 2016). This assumption, however, is challenged by more recent work that controls for measurement artifacts such as changing tests and test scaling. These studies find, at most, small associations of summer achievement loss with poverty or mothers' education level (Hippel \& Hamrock, 2019; Kuhfeld, 2019). Widening the focus on the whole school year, a study based on a nationally representative longitudinal dataset takes a closer look at family investments as one potential driving force behind SES achievement gaps. Initial SES gaps in math and science skills turned out to slightly increase (with small effect sizes between 0.01 and $0.02 S D$ units per 3 months of exposure) in the first 3 years of primary school. While SES skills gaps in science grew during the school year, skills gaps in math intensified during the summer months. Family investments involving home learning activities and out-of-home enrichment activities could partly explain exacerbation of SES performance gaps (Coley et al., 2020). Data from Switzerland and Germany, gathered during the COVID-19 pandemic, indicate reductions in children's studying time of more than $3 \mathrm{~h}$ per day. Neither study, however, found considerable differences in studying time as a function of parental education (Grätz \& Lipps, 2021; Wößmann et al., 2020). These data, however, do not preclude the possibility of SES-related differences in the quality of the learning activities during studying time. Despite the controversy on the extent of the influence of SES on students' quality and quantity of learning from home, we consider family SES as general learning condition to paint a comprehensive picture of the resources available to diverse studentsespecially since it is particularly the group of students from low-SES families who struggle most in mathematics (Valero et al., 2015).

Regarding the general teacher support provided in regular school contexts (not pandemic-specific), one central assumption in self-determination theory states that it is 
not the teacher's behavior per se that influences student motivation and achievement but rather the perception of these behaviors from the student perspective (Spearman \& Watt, 2013; Stroet et al., 2013). Just as expectancy-value theory, self-determination theory attaches great importance to subjective (perceived) value as central motive for behavior. In addition, self-determination theory also stresses the influence of situational factors in the process of internalizing extrinsic values. This process is supported if situational factors are perceived as instrumental to the satisfaction of the basic psychological needs of competence, relatedness, and autonomy (Ryan \& Deci, 2020). Accordingly, we distinguish between students' perception of how they are informed about their own competence in mathematics during regular classroom teaching (competence support), students' perception of how their need for autonomy is addressed during mathematics instruction in school (autonomy support), and students' perception of their connectedness to other learners in mathematics classes (social relatedness; Deci \& Ryan, 2012; Ryan \& Deci, 2000). These perceptions influence the way students learn (e.g., Black \& Deci, 2000; Ryan \& Grolnick, 1986). Focusing on mathematics, autonomy-supportive instruction can have a positive effect on later mathematics motivation and achievement (Froiland et al., 2016; Gutiérrez et al., 2018; Wei et al., 2019). Stroet and colleagues (2013) report in their review article students' perceptions of needs-supportive instruction to be positively related to their motivation, engagement, and hence achievement.

\section{The present study}

Based on data from 7th-grade secondary school students in Germany gathered via an online survey at the end of the first school year during the COVID-19 pandemic in the summer 2020, we identify systematically occurring groups of students that differ in specific home learning conditions and general learning conditions, comprising internal and external factors related to mathematics learning from home. The resulting student profiles are described by their manifestations on these variables and interpreted as more or less afflicted by extended periods of remote schooling. This study thereby aims at providing insights into available and missing resources and underlying conditions for learning mathematics from home. Due to a lack of existing research on the topic, we decided against formulating exact hypotheses on group sizes and characteristics and, therefore, chose latent profile analysis as the method of analysis, as it allows detecting groups within a dataset without having to define group sizes or characteristics a priori (i.e., a data-driven approach; Gibson, 1959; Hofer \& Stern, 2016; and 8; Lazarsfeld \& Henry, 1968; Vermunt \& Magidson, 2002). We accordingly use the specific home learning internal factors perceived value and success of students' math learning from home, the external factors direct and indirect family support, as well as teacher support: material and teacher support: contact as profile indicator variables. The general learning conditions sustained attention, math performance, engagement, excessive demand, anxiety, interest, self-concept (all internal), SES (external), perceived autonomy support, perceived competence support, and perceived social relatedness support (external) are included as outcome variables associated with each profile that further contribute to profile formation. The resulting profile solution is described and interpreted in terms of students' internal and external resources to handle mathematics learning from home. 


\section{Methods}

\section{Sample and procedure}

The sample consists of $N=2237$ th-grade secondary school students from Germany $\left(M_{\text {age }}=12.84\right.$ years, $\left.S D_{\text {age }}=0.55\right)$ with $n=115$ female students, $n=106$ male students, and $n=2$ students who indicated that they do not fit in any of those categories. Students were acquired by contacting mathematics teachers from 18 schools in Bavaria, Germany; we were already in contact in the context of another project. We contacted eleven schools from the highest secondary school track (Gymnasium), and eight schools agreed to participate. From the seven lower track secondary schools (Mittelschule) that we contacted, two schools were willing to participate. Schools participated with one to five classrooms, depending on school size. The participating school's 7th-grade mathematics teachers distributed information material to the students and their parents, and the parents' written consent was obtained. All students whose parents agreed to participate in the study received a link to our online survey in July 2020 to be completed in the next weeks until the end of the school year as voluntary homework assignment. From March to end of May 2020, students were learning completely from home. Since June 2020, most students were learning partly from home and partly at school. The survey was run via a secure and established tool (Unipark) conforming with the General Data Protection Regulation. The survey could be accessed from both desktop or laptop computers and touch screen devices like tablets or smartphones. The students could click through the survey at their own pace. The last page of the survey was linked to the web-based version of the sustained attention test that is described below in more detail. The whole assessment was intended to be completed in approximately $30 \mathrm{~min}$. After the end of the school year, in August 2020, we closed the survey and obtained the data. Altogether, $N=421$ people accessed the survey; however, only $N=223$ students produced valid datasets. The remaining $N=198$ participants did not finish the survey. The majority stopped in the first third of the survey. Because participation in the survey was not obligatory, the number of students from one class varied considerably-from one student to 23 students at the maximum. Due to the large variation and often small number of students per class, it was not possible to consider the classroom structure in our analyses. Thirty-nine of the students in the final sample attended the lowest and 184 students the highest secondary school track.

\section{Instruments and scales}

Table 1 provides essential information on all instruments and scales used to assess each of the internal and external factors (for more detailed information, please refer to the Online Resource "Instruments and Scales"). The self-report items are explicitly related to mathematics or mathematics instruction and learning, respectively. All questionnaire items in German language as well as a translated English version are available as Online Resource 1 . In addition to the central study variables, all students indicated their gender, the school type they attended, and the amount of time they spent on average per week on learning mathematics from home (scale: $1=$ no time, $2=$ less than $1 \mathrm{~h}$ per week, $3=1-2 \mathrm{~h}$ per week, $4=2-3 \mathrm{~h}$ per week, $5=3-4 \mathrm{~h}$ per week, $6=4-5 \mathrm{~h}$ per week, $7=$ more than $5 \mathrm{~h}$ per week). 


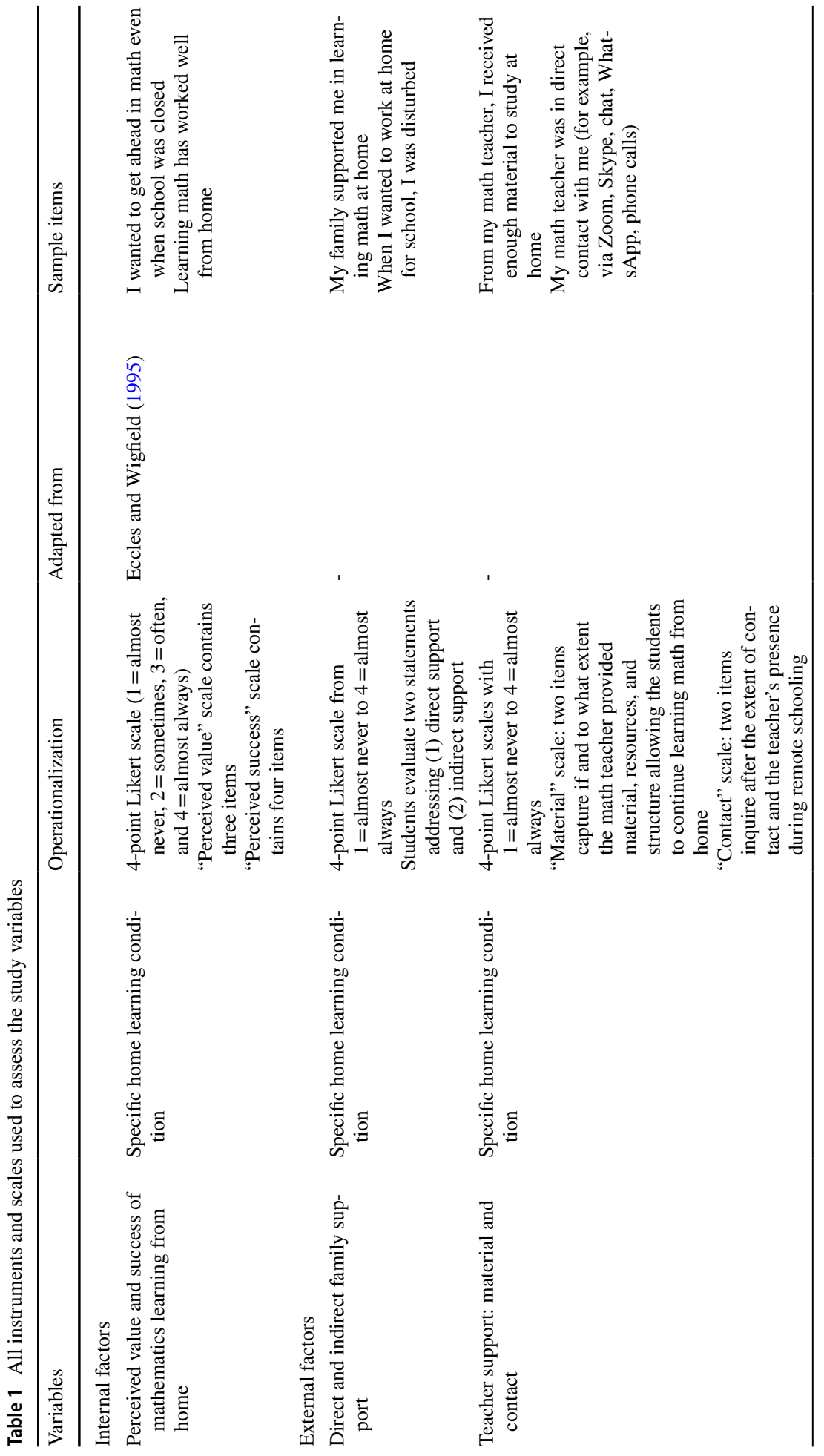




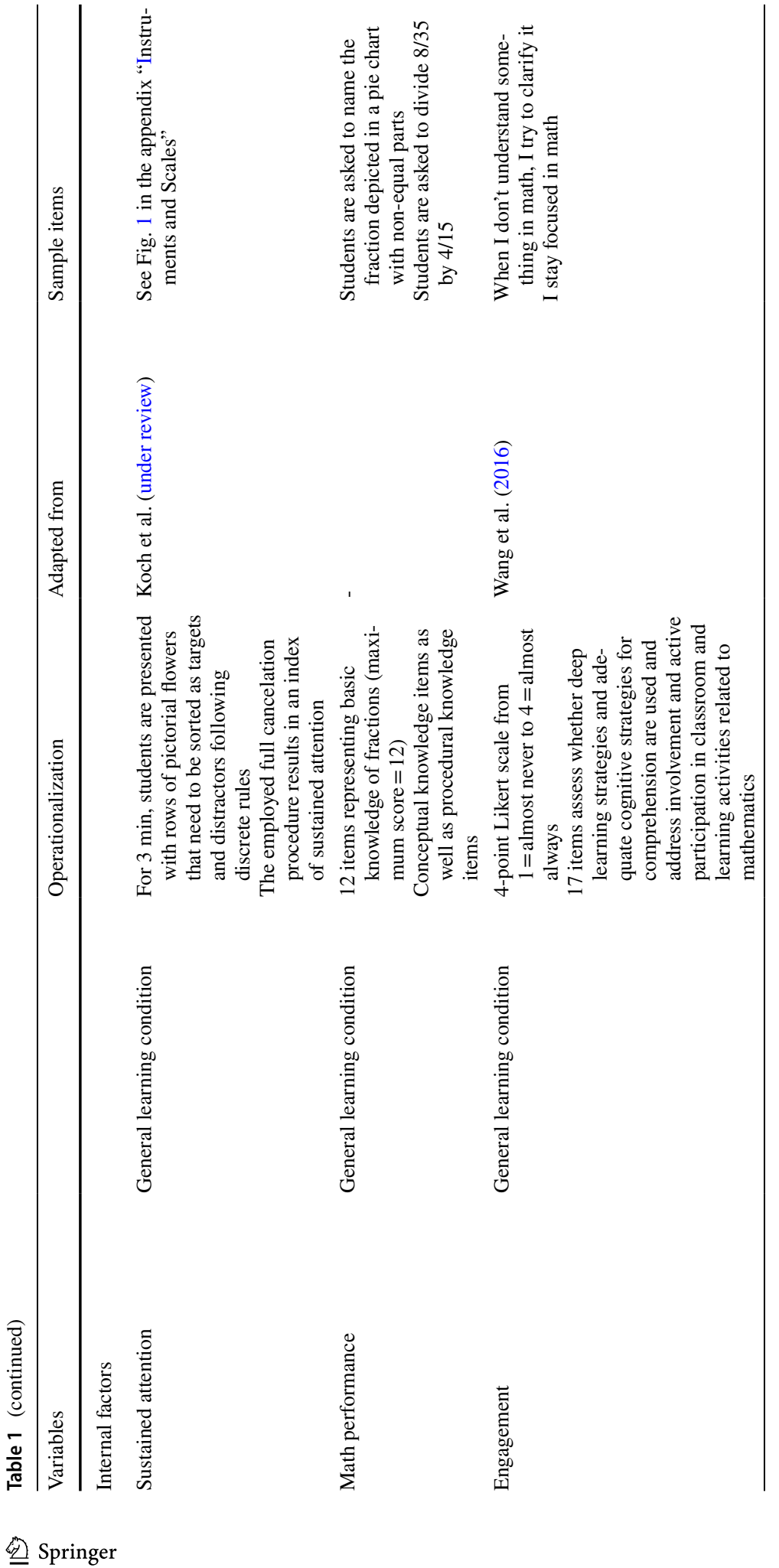




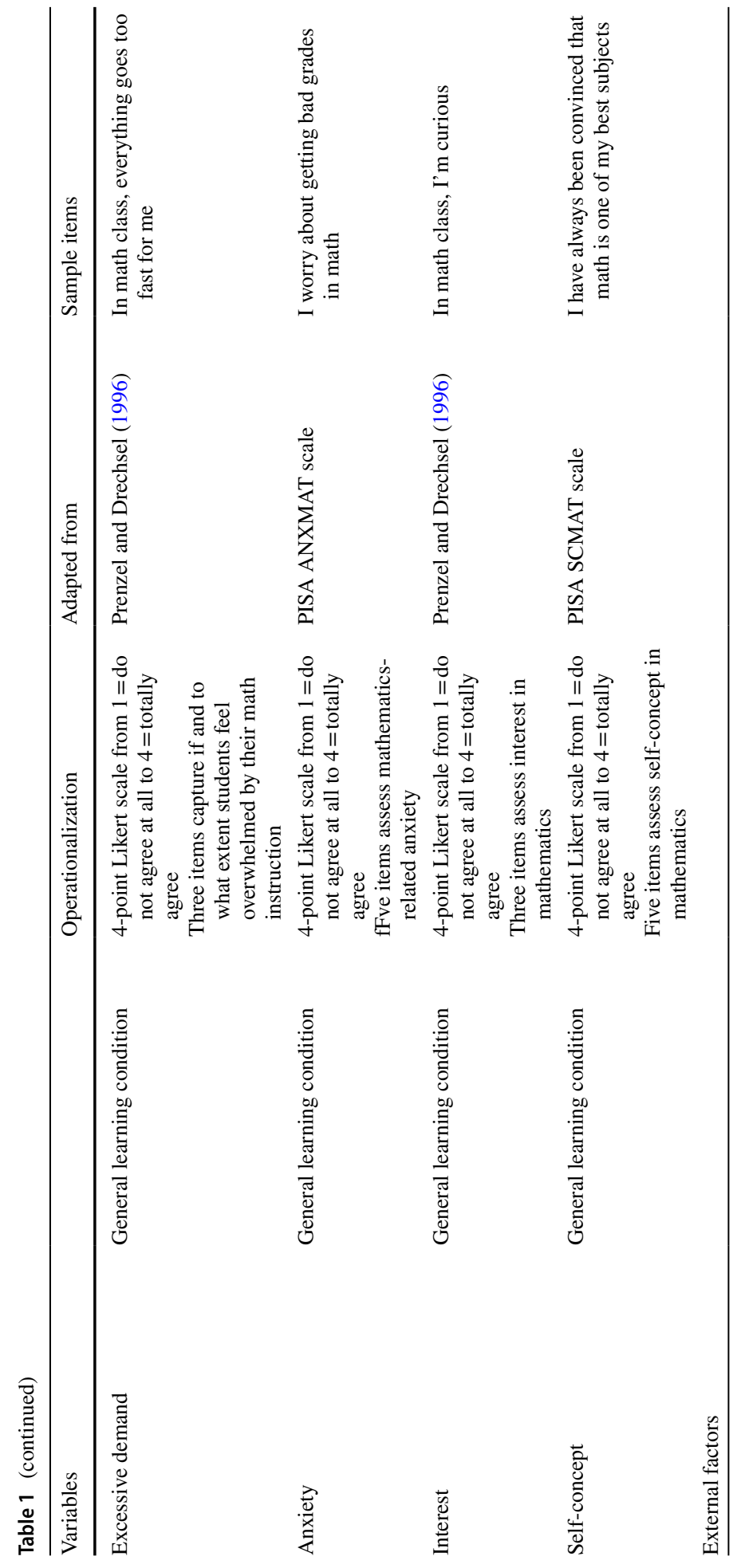


344

S. I. Hofer et al.

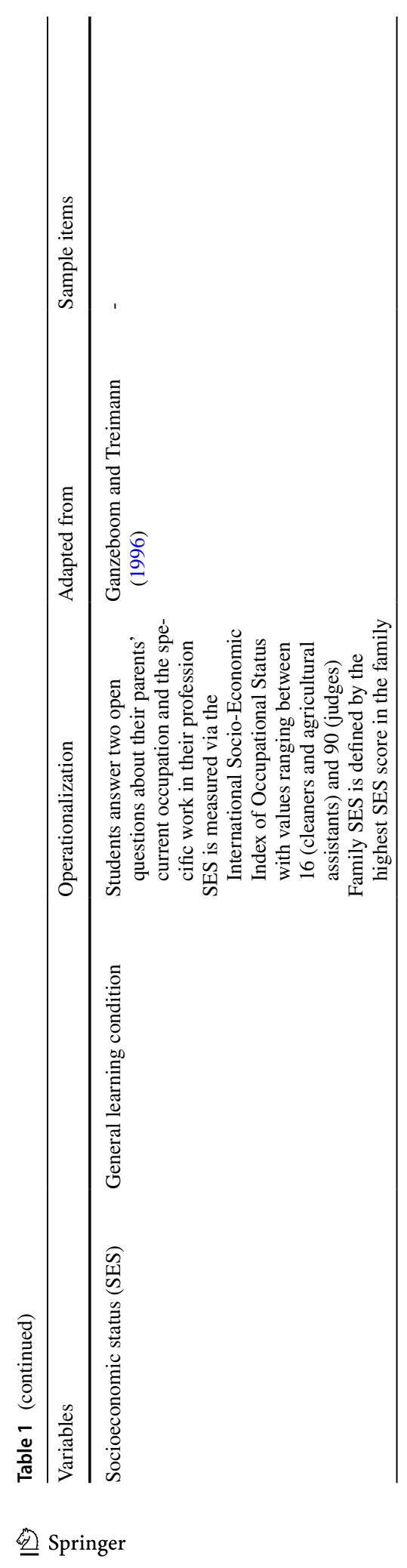




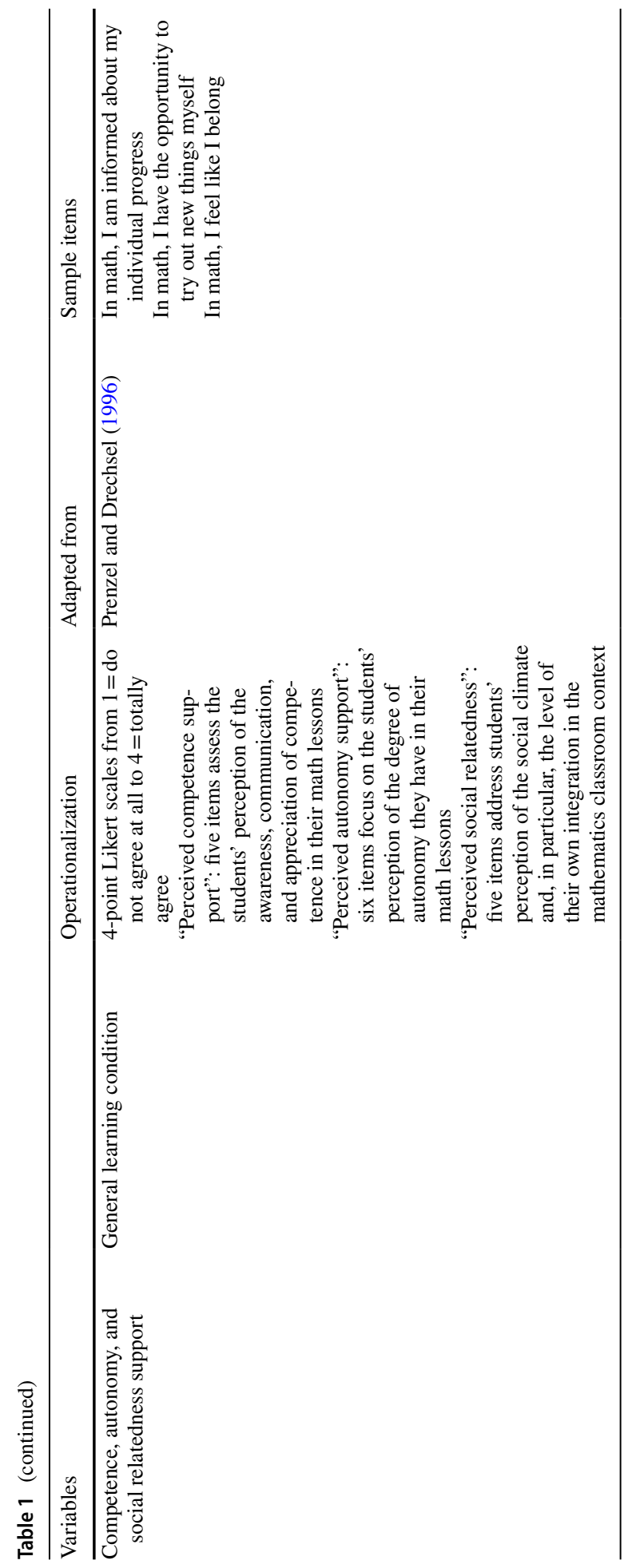




\section{Statistical analysis}

Data compilation and descriptive analyses were conducted in R-4.0.2. We applied latent profile analysis (LPA) to identify groups of students who differ systematically in terms of their internal and external resources to handle the demands of mathematics learning from home. The latent profile analyses were run with the software Mplus Version 8.4 (Muthén \& Muthén, 1998-2017) using robust maximum likelihood estimation. The six specific home learning internal and external factors directly associated with learning mathematics from home are included as indicator variables conceptually defining the profiles and guiding their interpretation. The eleven general learning internal and external factors that could be expected to affect the specific home learning conditions are considered outcome variables being associated with each estimated profile. Just as the specific home learning conditions, these general learning conditions accordingly contribute to profile formation. Profiles were hence estimated in one step based on all of the 17 variables (all specific home and general learning conditions). Conceptually, however, the six specific home learning conditions were used as the main descriptors for interpreting the profiles. In order to determine the number of profiles, models with two to five profiles were estimated. Solutions with a higher number of profiles were not only more difficult to interpret but also computationally more complex resulting in less trustworthy solutions given the high number of free parameters. We assessed model fit (i.e., the correspondence between data and the specified latent profile model) for each of the two-to-five-profile solutions by comparing Information Criteria (ICs), looking for the solutions with the lowest (i.e., best) IC values (see, e.g., Geiser, 2011; Gollwitzer, 2012). In line with recommendations of simulation studies, we examined the samplesize adjusted Bayesian Information Criterion (aBIC; Nylund et al., 2007; Sclove, 1987; Tofighi \& Enders, 2007; Yang, 2006; Yang \& Yang, 2007) and the standard Bayesian Information Criterion (BIC; Schwarz, 1978). In addition, we inspected the Vuong-LoMendell-Rubin (VLMR) likelihood ratio test and the entropy of each profile solution, which indicates the quality of the classification of the students into the estimated profiles. An entropy $=1$ would describe perfect, unambiguous classification.

There is no missing data in our final dataset with the exception of two general learning factors: family SES and sustained attention. Twenty-six students did not (reasonably) indicate their parents' occupation, and $n=73$ students did not finish the sustained attention test resulting in invalid measures. However, since the proportion of data that was not missing was sufficient for model estimation, we followed the available case approach (pairwise deletion).

\section{Results}

Table 2 provides the means and standard deviations for all study variables as well as the number of items and reliability estimates, whereas all intercorrelations are available in Table 3. There were neither floor nor ceiling effects on any of the variables. Reliability estimates range between 0.62 (for the two-item scale teacher support contact) and 0.92 . 
Table 2 Means, standard deviations, and reliability estimates for the study variables

\begin{tabular}{|c|c|c|c|c|c|c|}
\hline \multirow[b]{2}{*}{ Variables } & & \multirow[b]{2}{*}{$M$} & \multirow[b]{2}{*}{$S D$} & \multirow[b]{2}{*}{$\begin{array}{l}\text { Number } \\
\text { of items }\end{array}$} & \multicolumn{2}{|c|}{$\begin{array}{l}\text { Reliabil- } \\
\text { ity }\end{array}$} \\
\hline & & & & & $\alpha$ & $\omega$ \\
\hline \multicolumn{7}{|l|}{ Internal } \\
\hline Perceived success & Specific home learning condition & 3.20 & 0.65 & 4 & .78 & .83 \\
\hline $\begin{array}{l}\text { Perceived value } \\
\text { Family support (external) }\end{array}$ & Specific home learning condition & 2.98 & 0.75 & 3 & .74 & .75 \\
\hline Direct family support & Specific home learning condition & 2.67 & 1.04 & 1 & -- & - \\
\hline \multicolumn{7}{|l|}{ Teacher support (external) } \\
\hline Teacher support material & Specific home learning condition & 3.71 & 0.56 & 2 & .78 & -- \\
\hline $\begin{array}{l}\text { Teacher support contact } \\
\text { Internal }\end{array}$ & Specific home learning condition & 3.05 & 0.89 & 2 & .62 & -- \\
\hline Sustained attention & General learning condition & 8.37 & 26.40 & -- & $.86^{\mathrm{a}}$ & -- \\
\hline Math performance & General learning condition & 8.65 & 3.55 & 12 & .89 & .91 \\
\hline Engagement & General learning condition & 3.05 & 0.48 & 17 & .87 & .90 \\
\hline Excessive demand & General learning condition & 2.01 & 0.68 & 3 & .80 & .81 \\
\hline Anxiety & General learning condition & 1.97 & 0.77 & 5 & .89 & .92 \\
\hline Interest & General learning condition & 2.55 & 0.71 & 3 & .82 & .83 \\
\hline Self-concept & General learning condition & 2.62 & 0.74 & 5 & .88 & .91 \\
\hline \multicolumn{7}{|l|}{ Family support (external) } \\
\hline SES & General learning condition & 61.59 & 16.17 & -- & -- & -- \\
\hline \multicolumn{7}{|l|}{ Teacher support (external) } \\
\hline Perceived autonomy support & General learning condition & 2.81 & 0.49 & 6 & .64 & .75 \\
\hline Perceived competence support & General learning condition & 3.05 & 0.56 & 5 & .73 & .77 \\
\hline Perceived social relatedness & General learning condition & 3.04 & 0.61 & 5 & .80 & .84 \\
\hline
\end{tabular}

Note. $M$ mean, $S D$ standard deviation

${ }^{\text {a }}$ To estimate the reliability of sustained attention, the split-half reliability has been estimated. To avoid overestimation, this split was carried out by separating the items at the $90 \mathrm{~s}$ mark (i.e., after half of the test time has passed)

\section{Identification of profile number}

When comparing the solutions with two to five profiles, the four-profile solution fitted the data best (see Table 4). It showed the lowest (i.e., best) BIC, which sanctions complexity more than other information criteria (see Bacci et al., 2014). The aBIC would have suggested the five-profile solution and, secondly, the four-profile solution. The five-profile solution, however, led to problems with the estimation of the standard errors of model parameters (as was the case with all solutions with $k>4$ ). Entropies were high (above 0.80) for all profile solutions. The Vuong-Lo-Mendell-Rubin (VLMR) likelihood ratio test indicated the only significant increase in model fit when comparing the oneprofile solution to the two-profile solution-emphasizing that a nuanced person-centered perspective may be preferred to a variable-centered approach. In line with Marsh 


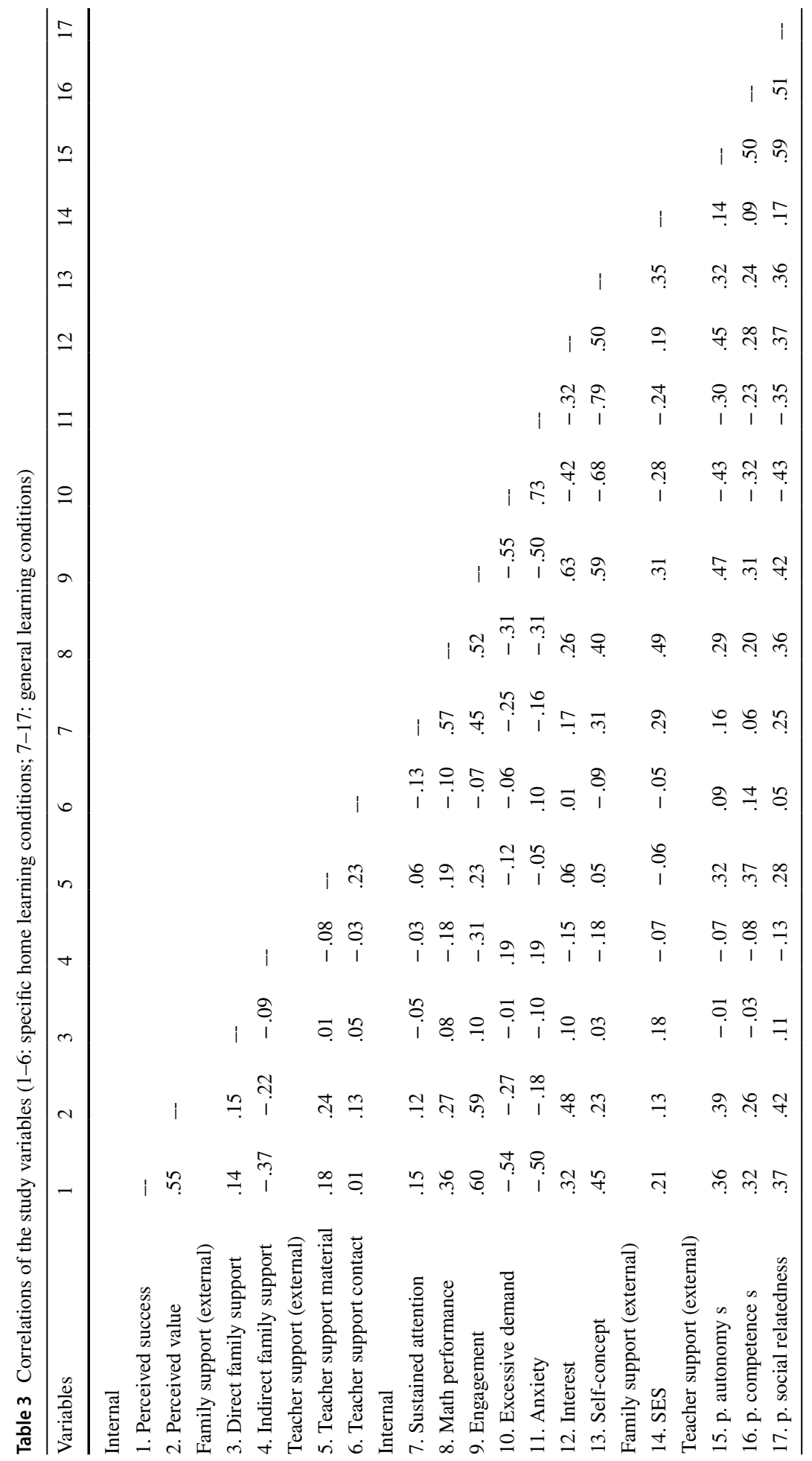


Table 4 Logarithmized likelihood (Log L), number of parameters (k), aBIC, BIC, the Vuong-Lo-MendellRubin (VLMR) likelihood ratio test, and the entropy for different LPA solutions

\begin{tabular}{lllllll}
\hline $\begin{array}{l}\text { Number of } \\
\text { profiles }\end{array}$ & Log $L$ & $k$ & aBIC & BIC & VLMR & Entropy \\
\hline 2 & -4887.54 & 63 & 9916.07 & $10,115.72$ & $p<0.001$ & 0.91 \\
3 & -4767.65 & 92 & 9741.20 & $10,032.76$ & $p=0.249$ & 0.89 \\
4 & -4675.05 & 121 & 9620.90 & $10,004.37$ & $p=0.134$ & 0.92 \\
5 & -4599.50 & 150 & 9534.71 & $10,010.08$ & $p=0.157$ & 0.93 \\
\hline
\end{tabular}

et al. (2009), we also based our decision on the final profile solution on its theoretical meaningfulness, parsimony, and interpretability.

Since the final four-profile model fitted the data worse when within-profile correlations between the six indicator variables (i.e., the six specific home learning conditions: perceived success, perceived value, direct family support, indirect family support, teacher support material, teacher support contact) were set free, we could assume to meet the assumption of local independence implying that the indicator variables are uncorrelated within each profile (Lazarsfeld \& Henry, 1968). Moreover, model estimation improved with the variance of each indicator variable being constrained to be equal across profiles compared to unrestricted estimation. Consequently, there was no need to relax the homogeneity of variance assumption.

\section{Description of the final profile solution based on the six specific home learning internal and external factors}

Figure 2 depicts the mean estimated values on the six indicator variables for the four profiles with error bars representing the $95 \%$ confidence intervals. These estimates are also provided in Table 5 together with profile-specific membership proportions and counts. Although, in LPA, individuals are not deterministically but rather probabilistically assigned to each profile, group-size specifications are based on the most likely latent profile membership for each student. In the following, we describe each of the profiles along the six specific home learning internal and external factors that directly reflect students' resources to handle mathematics learning from home. Our analyses are not confirmatory in the sense

Fig. 2 Estimated means on the six specific home learning indicator variables for the four profiles, with error bars representing the $95 \%$ confidence intervals

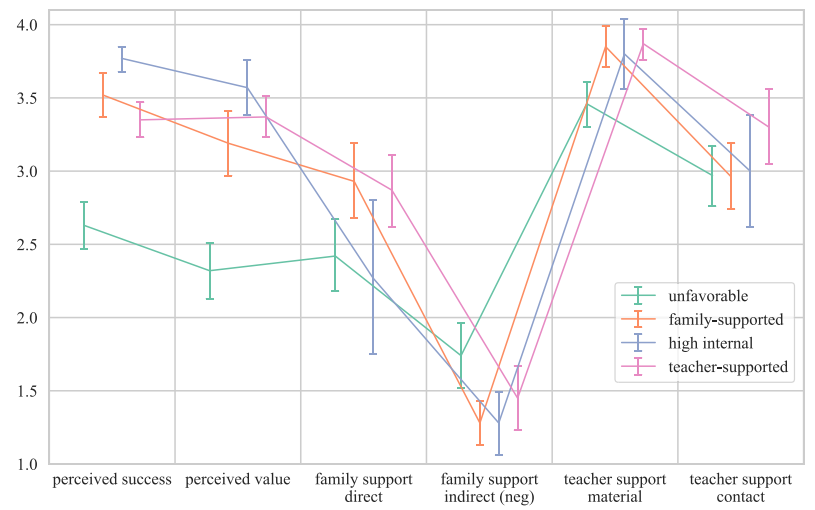




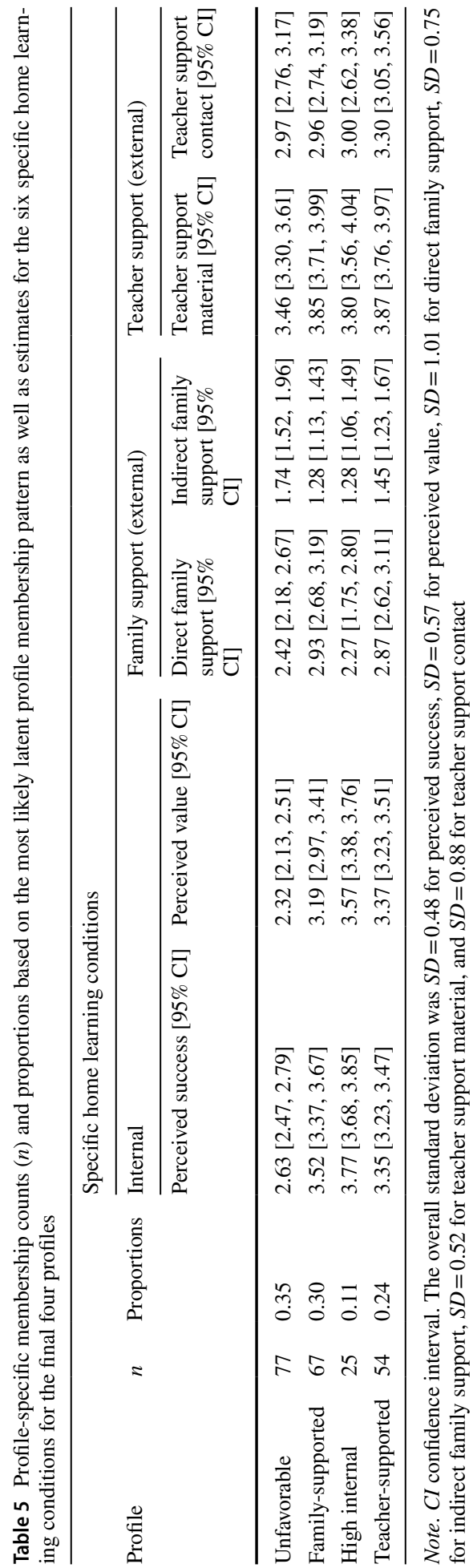


that we test a specific model or hypothesis. We rather apply an explorative approach to learn more about potential student profiles related to resources for learning from home. We hence conduct significance tests to compare the estimated means between the profiles for our profile indicator variables (the specific home learning conditions, which are conceptually at the center of our profiles), but not for the general learning conditions that were estimated as profile outcomes (see "Profile-specific internal and external general learning factors related to learning mathematics from home" section). All comparisons (i.e., significance tests) between the profile indicators are provided as Online Resource 2 and based on the chi-square value $(\chi 2)$ of the Wald test of parameter constraints.

\section{Unfavorable profile}

Students in this profile (35\% of the sample) show the lowest values of all students in the sample in terms of both internal factors perceived success and perceived value of learning math from home. They only sometimes received direct support from their family and were sometimes disturbed when learning at home for school, which indicated less indirect family support (i.e., more disturbances) than all other students in the sample. These students received regular teacher support in terms of the provision of material but again the least support in the sample. Similar to almost all other profiles, students in this profile reported regular teacher support with a focus on the teacher's presence during remote schooling. Given the overall rather unfavorable internal and external conditions regarding learning for mathematics from home relative to the rest of the sample, this profile can be described as unfavorable. About $30 \%$ of all female and $41 \%$ of all male students in the sample could be categorized into this profile. Moreover, $25 \%$ of all students from the highest secondary school track and $79 \%$ of all students from the lower secondary school track belong to the unfavorable profile. These students, on the average, spend 2-3 h per week on learning mathematics from home $(M=3.92, S E=0.15)$. Based on the $\mathrm{BCH}$ method for distal outcomes (Asparouhov \& Muthén, 2014; Bakk \& Vermunt, 2016), which is implemented in Mplus and applies a corrected three-step approach to include auxiliary variables (i.e., distal outcomes) in the model without affecting the model estimates (e.g., profile sizes and characteristics), the estimate of the average time spent on learning mathematics from home for this profile was significantly smaller than all but the family-supported profile (all $p s<0.05)$.

\section{Family-supported profile}

The students in this profile (30\% of the sample) are characterized by rather high success expectancies with high-to-medium perceived task value compared to the other students in the sample. They show the highest manifestations on direct family support and-together with the next profile - the highest indirect family support (i.e., the least disturbances). Their estimates in terms of both teacher support indicators are inconspicuous. Accordingly, these students stand out by their consistently high family support during learning from home. Almost $34 \%$ of the female students and $26 \%$ of the male students as well as $36 \%$ of the highest secondary school track students and no student from the lower secondary school track were in this profile. Similar to the unfavorable profile, students in this profile also spend approximately $2-3 \mathrm{~h}$ per week on learning mathematics from home $(M=4.23$, $S E=0.15)$. 


\section{High internal profile}

This profile comprises $11 \%$ of the sample and is characterized by the highest manifestations on both specific home learning internal factors in the sample. They also indicated the lowest direct family support compared to all other students, however, combined with the highest indirect family support (together with the family-supported profile). With both teacher support indicators showing no striking deviations, these students are referred to as the high internal profile. This profile comprises $6 \%$ of all female and $17 \%$ of all male students as well as $13 \%$ of all highest secondary school track students and $3 \%$ of all lower secondary school track students. These students spend around 3-4 h per week with learning mathematics from home $(M=4.77, S E=0.29)$.

\section{Teacher-supported profile}

Finally, the remaining $24 \%$ of the students indicated high-to-medium success expectancies and rather high perceived task value compared to the other students in the sample. They seem to regularly receive direct family support (similar to the family-supported profile) and show rather average manifestations in terms of indirect family support relative to the rest of the students. Just as most of the other profiles (except for the unfavorable profile), these students reported that their teachers almost always provided the material and resources necessary to learn mathematics from home-even with the highest estimate compared to the other profiles. However, this profile particularly stood out by its high manifestation on the second teacher support indicator, inquiring after the presence of the teacher during remote schooling. Due to the consistently high ratings on both teacher support indicators, we label this profile as the teacher-supported profile. About $30 \%$ of the female students, $16 \%$ of the male students and the two students who indicated being neither male nor female belonged to this profile. This profile further encompasses $26 \%$ of the highest secondary school track and $18 \%$ of the lower secondary school track students. Students in this profile also reported to spend around 3-4 h per week with learning mathematics from home $(M=4.55, S E=0.18)$.

\section{Profile-specific internal and external general learning factors related to learning mathematics from home}

Table 6 lists the estimated means, standard deviations, and 95\% confidence intervals for all general learning factors that were estimated as profile outcomes. Figure 3 and Figure 4 provide the corresponding graphical representation. The profile comparisons reported in the following are based on an inspection of the confidence intervals.

As presented in Table 6, the unfavorable profile indeed shows the lowest manifestations on all general learning internal and external factors except for self-concept in mathematics. This variable was rated slightly lower by students in the teacher-supported profile. Students in the family-supported profile indeed had the highest family SEStogether with the high internal profile. The same holds for math performance and sustained attention. In addition to the beneficial manifestations on these two internal factors and family support (SES), the high internal profile also yielded the highest estimates on all remaining general learning internal factors. Interestingly, also their average ratings in terms of perceived competence, autonomy, and social relatedness support turned out to 
Table 6 Means, standard deviations, and 95\% confidence intervals for the eleven general learning conditions estimated for each of the final four profiles

\begin{tabular}{|c|c|c|c|c|}
\hline General learning conditions & Profile & $M$ & $S D$ & $95 \% \mathrm{CI}$ \\
\hline \multicolumn{5}{|l|}{ Internal } \\
\hline Sustained attention & $\begin{array}{l}\text { Unfavorable } \\
\text { Family-supported } \\
\text { High internal } \\
\text { Teacher-supported }\end{array}$ & $\begin{array}{l}-2.48 \\
21.40 \\
14.35 \\
2.20\end{array}$ & $\begin{array}{l}31.01 \\
12.95 \\
17.10 \\
28.37\end{array}$ & $\begin{array}{l}{[-11.83,5.37]} \\
{[17.38,25.41]} \\
{[6.30,22.41]} \\
{[-8.94,13.33]}\end{array}$ \\
\hline Math performance & $\begin{array}{l}\text { Unfavorable } \\
\text { Family-supported } \\
\text { High internal } \\
\text { Teacher-supported }\end{array}$ & $\begin{array}{l}6.31 \\
11.20 \\
10.18 \\
8.20\end{array}$ & $\begin{array}{l}3.96 \\
0.89 \\
2.33 \\
2.95\end{array}$ & $\begin{array}{l}{[5.28,7.33]} \\
{[10.89,11.52]} \\
{[9.22,11.14]} \\
{[7.16,9.23]}\end{array}$ \\
\hline Engagement & $\begin{array}{l}\text { Unfavorable } \\
\text { Family-supported } \\
\text { High internal } \\
\text { Teacher-supported }\end{array}$ & $\begin{array}{l}2.57 \\
3.39 \\
3.54 \\
3.11\end{array}$ & $\begin{array}{l}0.34 \\
0.28 \\
0.23 \\
0.30\end{array}$ & $\begin{array}{l}{[2.47,2.66]} \\
{[3.30,3.48]} \\
{[3.44,3.64]} \\
{[2.99,3.22]}\end{array}$ \\
\hline Excessive demand & $\begin{array}{l}\text { Unfavorable } \\
\text { Family-supported } \\
\text { High internal } \\
\text { Teacher-supported }\end{array}$ & $\begin{array}{l}2.51 \\
1.64 \\
1.08 \\
2.17\end{array}$ & $\begin{array}{l}0.66 \\
0.36 \\
0.14 \\
0.42\end{array}$ & $\begin{array}{l}{[2.34,2.68]} \\
{[1.53,1.74]} \\
{[1.01,1.14]} \\
{[2.00,2.35]}\end{array}$ \\
\hline Anxiety & $\begin{array}{l}\text { Unfavorable } \\
\text { Family-supported } \\
\text { High internal } \\
\text { Teacher-supported }\end{array}$ & $\begin{array}{l}2.41 \\
1.51 \\
1.04 \\
2.32\end{array}$ & $\begin{array}{l}0.79 \\
0.34 \\
0.08 \\
0.56\end{array}$ & $\begin{array}{l}{[2.20,2.61]} \\
{[1.40,1.62]} \\
{[1.00,1.08]} \\
{[2.11,2.53]}\end{array}$ \\
\hline Interest & $\begin{array}{l}\text { Unfavorable } \\
\text { Family-supported } \\
\text { High internal } \\
\text { Teacher-supported }\end{array}$ & $\begin{array}{l}2.06 \\
2.81 \\
3.44 \\
2.54\end{array}$ & $\begin{array}{l}0.57 \\
0.63 \\
0.40 \\
0.52\end{array}$ & $\begin{array}{l}{[1.91,2.22]} \\
{[2.65,2.97]} \\
{[3.27,3.62]} \\
{[2.39,2.70]}\end{array}$ \\
\hline Self-concept & $\begin{array}{l}\text { Unfavorable } \\
\text { Family-supported } \\
\text { High internal } \\
\text { Teacher-supported }\end{array}$ & $\begin{array}{l}2.19 \\
3.12 \\
3.64 \\
2.18\end{array}$ & $\begin{array}{l}0.62 \\
0.39 \\
0.35 \\
0.45\end{array}$ & $\begin{array}{l}{[2.02,2.36]} \\
{[2.99,3.25]} \\
{[3.50,3.78]} \\
{[2.01,2.36]}\end{array}$ \\
\hline Family support (external): SES & $\begin{array}{l}\text { Unfavorable } \\
\text { Family-supported } \\
\text { High internal } \\
\text { Teacher-supported }\end{array}$ & $\begin{array}{l}55.57 \\
67.48 \\
68.54 \\
58.82\end{array}$ & $\begin{array}{l}18.85 \\
10.85 \\
11.22 \\
16.04\end{array}$ & $\begin{array}{l}{[50.46,60.67]} \\
{[63.75,71.22]} \\
{[63.74,73.35]} \\
{[53.82,63.83]}\end{array}$ \\
\hline \multicolumn{5}{|l|}{ Teacher support (external) } \\
\hline Perceived autonomy support & $\begin{array}{l}\text { Unfavorable } \\
\text { Family-supported } \\
\text { High internal } \\
\text { Teacher-supported }\end{array}$ & $\begin{array}{l}2.49 \\
2.93 \\
3.37 \\
2.87\end{array}$ & $\begin{array}{l}0.43 \\
0.41 \\
0.37 \\
0.39\end{array}$ & $\begin{array}{l}{[2.38,2.60]} \\
{[2.82,3.05]} \\
{[3.21,3.52]} \\
{[2.75,2.98]}\end{array}$ \\
\hline Perceived competence support & $\begin{array}{l}\text { Unfavorable } \\
\text { Family-supported } \\
\text { High internal } \\
\text { Teacher-supported }\end{array}$ & $\begin{array}{l}2.76 \\
3.12 \\
3.63 \\
3.11\end{array}$ & $\begin{array}{l}0.52 \\
0.55 \\
0.30 \\
0.44\end{array}$ & $\begin{array}{l}{[2.64,2.88]} \\
{[2.97,3.27]} \\
{[3.48,3.77]} \\
{[2.96,3.26]}\end{array}$ \\
\hline Perceived social relatedness & $\begin{array}{l}\text { Unfavorable } \\
\text { Family-supported } \\
\text { High internal } \\
\text { Teacher-supported }\end{array}$ & $\begin{array}{l}2.62 \\
3.27 \\
3.55 \\
3.12\end{array}$ & $\begin{array}{l}0.61 \\
0.43 \\
0.42 \\
0.49\end{array}$ & $\begin{array}{l}{[2.46,2.77]} \\
{[3.16,3.39]} \\
{[3.38,3.72]} \\
{[2.96,3.28]}\end{array}$ \\
\hline
\end{tabular}

Note. CI confidence interval 
Fig. 3 Estimated means on the Likert-scale general learning conditions that were estimated as profile outcomes, with error bars representing the $95 \%$ confidence intervals
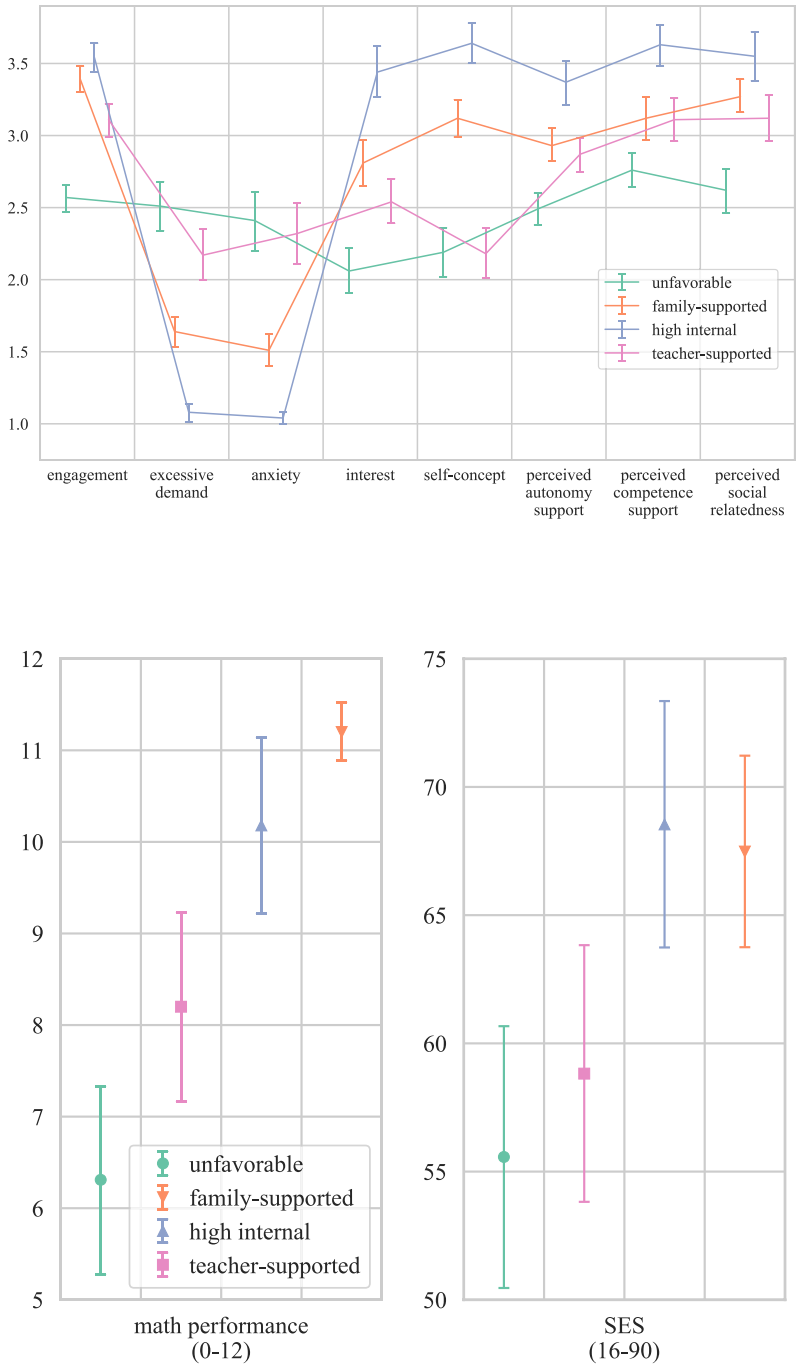

Fig. 4 Estimated means on the general learning conditions sustained attention, math performance, and SES that were estimated as profile outcomes with error bars representing the $95 \%$ confidence intervals

be higher compared to the rest of the sample. The teacher-supported profile, by contrast, showed only average values on these three variables relative to the other students in the sample. While their family SES was comparable to the students in the unfavorable profile, their math performance was higher but still lower than the performance of the students in the other two profiles. In terms of all other general learning internal factors (except for self-concept in mathematics), descriptively, they showed higher manifestations than the unfavorable profile but scored below the other two profiles.

Despite the overall less beneficial general learning conditions, students in the teachersupported profile did not considerably differ from students in the high internal and family-supported profiles in terms of the specific home learning conditions: They only significantly differed from the high internal profile in terms of perceived success and direct 
family support and did not significantly differ at all from the family-supported profile. Nevertheless, descriptively, they showed the highest manifestations on teacher support.

\section{Discussion}

In this study, we wanted to find out more about potential differences in the internal and external resources available to students during remote schooling, focusing on secondary school mathematics. We hence identified profiles characterized by students' perceived success and value of learning from home (specific home learning internal factors) and their families' as well as their teachers' support during this time (specific home learning external factors). We related these profiles, which are based on internal and external factors directly associated with learning from home, to more general underlying factors (general learning internal and external factors) such as the student's cognitive and motivational-affective prerequisites, the family's SES and the teachers' competence, autonomy, and social relatedness support during mathematics instruction as perceived by the students. These general learning conditions were intended to further explain the profiles and inform profile interpretation. An adapted version of the Supply-Use-Model (Brühwiler \& Blatchford, 2011) was used as an overarching framework to embed our variables (the specific home learning and general learning conditions) and describe their relations. Latent profile analyses suggested a four-profile solution. We labeled the resulting four profiles as the unfavorable, the family-supported, the high internal, and the teacher-supported profile. In the following, we try to synthesize all of the information available to provide a comprehensive interpretation of the four profiles.

\section{Interpretation of the profiles}

Students in three of the four profiles similarly report frequent teacher support in terms of teacher presence and contact. Only students in the teacher-supported profile on average showed higher manifestations. Although teachers were not consistently perceived as "present" during remote schooling, all but the unfavorable profile indicated that their mathematics teachers almost always provided the material and resources necessary to learn from home, representing a slightly more positive picture than existing research that reported rather large variance in the guidance and structure provided by teachers outside the regular school context (Eickelmann \& Drossel, 2020; Lohr et al., 2021; Ortiz, 2020; Wößmann et al., 2020). Students in the unfavorable profile, however, also showed significantly lower manifestations on this variable - as well as on all of the three general learning conditions related to teacher support in the mathematics classroom (i.e., competence support, autonomy support, and social relatedness) that have been found to be positively related to students' motivation, engagement, and hence achievement (e.g., Stroet et al., 2013; Wei et al., 2019). So, they face rather unfavorable external conditions, especially since teaching quality and maintaining close contact seem to be particularly important during remote schooling over and above home resources (Bansak \& Starr, 2021; Hofer et al., 2021; Huber \& Helm, 2020; Köller et al., 2020).

Regarding direct family support, both the teacher- and the family-supported profiles reported frequent assistance by family members during math learning. A supportive home learning environment-including a dedicated study place at home-can be considered an important protective factor compensating for missing routines and assistance during remote 
schooling (Andrew et al., 2020; Coley et al., 2020; Köller et al., 2020). Students in the high internal profile might have indicated lower direct family support for math learning because they did not perceive a high need for external support given their high internal resources. This argumentation, however, does not hold for students in the unfavorable profile who also reported less direct family support, combined with the least beneficial manifestations on indirect family support-suggesting a higher frequency of disturbances-compared to the other profiles. These students hence lack at least some of the protective resources that a supportive home learning environment provides (Engzell et al., 2021).

While the unfavorable and the teacher-supported profiles both could be described by a comparably low family SES, the latter profile seems to be equipped with task values related to math learning from home not significantly different from the high internal profile, average success expectancies, and, importantly, high teacher and direct family support. It seems that students in the teacher-supported profile can profit from particularly engaged teachers and a family that provides assistance during math learning from home. Being aware of and encouraged by these external resources might contribute to their expectations of success and the subjective value they assign to math learning from home, which, in turn, have been shown to be related to students' motivation to engage in (self-regulated) learning (e.g., Artino \& Stephens, 2006; Bergey et al., 2018; Eccles \& Wigfield, 2002; Kosovich et al., 2017; Panadero \& Alonso Tapia, 2014). These resources are not available to students in the unfavorable profile, who accordingly also show the lowest level of engagement and interest in mathematics as compared to all other profiles.

Nearly half of all male students in the sample and more than three quarters of the students from the lower secondary school track belonged to the unfavorable profile. Given that they already demonstrated the lowest mathematics performance in the sample, which is consistent with existing findings relating low SES with more difficulties in mathematics at school (Valero et al., 2015), a prolonged period of intensified learning from home might be particularly harmful for this group of students and considerably increase existing deficits. Although the mere quantity of time students spend with learning mathematics from home is no indicator of the quality or effective learning time (e.g., Romero \& Barberà, 2011), students in the unfavorable profile on the average invested significantly less time than all other profiles except for the family-supported profile. While other studies did not find considerable differences in studying time as a function of parental education (Grätz \& Lipps, 2021; Wößmann et al., 2020), the person-centered approach used in the present study indicates that low family SES (similar to parental education) can be associated with less studying time during the pandemic if it is accompanied by additional rather detrimental conditions. More generally, our person-centered approach can at least partially explain inconsistent results on the extent of the influence of SES on students' quality and quantity of learning from home (e.g., Coley et al., 2020; Grätz \& Lipps, 2021; Wößmann et al., 2020): Students in the teacher-supported profile, who also showed a comparably low family SES similar to those in the unfavorable profile, nevertheless could rely on a number of protective factors, such as rather high direct family support, teacher support, and task value.

The high internal and the family-supported profile, in turn, are similar in terms of sustained attention and math performance as well as family SES. The high internal profile, however, is characterized by higher manifestations on all other specific home learning and general learning internal factors and on the general learning conditions related to teacher support (i.e., competence support, autonomy support, and social relatedness). The latter might indicate that these variables-being self-reported and referring to the students' perception of the teacher's instruction - to a large extent reflect the interaction between students' internal resources and the teacher's support during instruction (e.g., Flunger et al., 
2019; Seidel, 2007). Two interrelated, additive effects could be expected: Teachers might react differently to motivated, eager, and high-performing students, and these students might perceive math instruction as more satisfying than other students. (The same arguments apply, of course, to the comparatively low expressions of these variables among students in the unfavorable profile-just the other way around.) While there are more female students in the family-supported profile, there are more male students in the high internal profile. Since we focus on mathematics in this study, a male overrepresentation in the high internal profile is well in line with existing research showing a male advantage in terms of motivational-affective variables in the domain of mathematics and STEM more general (e.g., Hofer \& Stern, 2016; Reinhold et al., 2019).

Our results complement with the findings by Schult et al. (2021) and Engzell et al. (2021) who reported pronounced negative effects of the pandemic on competence development for students from families with low socio-cultural capital. While we did not assess students' competence development during the pandemic, this study contributes to a more differentiated understanding of potential detrimental and protective factors accounting for or preserving against learning loss.

\section{Limitations}

A limitation of this study is that all measures are based on information provided by the students. This is inherently consistent as long as internal factors are concerned. With regard to direct and indirect family support and teacher support, measures that do not depend on the student's perception might be better suited to allow an objective assessment of the situation. However, ultimately, it is all about the students' handling of the situation. In consequence, their subjective assessment of external factors could also be considered adequate.

Unfortunately, a smaller proportion of lower than higher secondary school students participated in the study. Students attending the two different school types also differ systematically on a number of other variables (e.g., Götz et al., 2013; Sälzer et al., 2013). For instance, both existing research and our own data suggest that students from the lower secondary school track, on the average, come from families with lower SES than students from the highest secondary school track (e.g., Ditton \& Maaz, 2011; Stern \& Hofer, 2014). A more balanced sample accordingly might have resulted in even more differentiated profiles particularly as regards the description of students from the lower secondary school track. Closely related, there might be a more general selection bias in our sample, since students could opt in or out of the study on a voluntary basis. The students who participated and completed the survey could be assumed to differ systematically from those students not willing to participate or abandoning the survey (e.g., Hernán et al., 2004; Smart, 1966). Since we could expect the self-selection of students into the sample to rather result in disproportionally high manifestations on variables that are positively associated with educational success and perseverance, we might have missed to identify more unfavorable profiles. The profiles described in this study could hence be considered a slightly overoptimistic representation of the actual situation at secondary schools.

\section{Implications for research}

LPA and other person-centered analytical methods constitute fruitful approaches to capture individual differences in cognition, experience, and behavior (e.g., Hickendorff et al., 2017; Hofer et al., 2020). Students' handling of remote schooling or, more general, learning from 
home can be assumed to depend on multiple internal and external resources. Different combinations of resources could jointly constitute more or less beneficial conditions for remote schooling with high manifestations on one variable compensating for low manifestations on other variables. This multivariate perspective can be considered particularly valuable when strong unifying effects, for example, of classroom instruction, are absent-as it is the case when learning from home or during the summer break. While recent evidence indicates that demographic factors such as ethnicity or SES account for about four percent of the variability in learning during the summer break, overall, the way how students' competences develop shows higher variability during the summer months than during the school year (Atteberry \& McEachin, 2019; Kuhfeld et al., 2020)—suggesting different internal and external student variables, in addition to SES, to contribute to knowledge development in times without collective classroom instruction.

By contrast, the manifestations of individual variables, inspected in isolation, might be of little value for the prediction of a student's success to learn mathematics - or any other subject-from home. When trying to describe and understand differences in experience and behavior that are most likely influenced by multiple internal and external variables, an idiosyncratic approach might be preferred over a nomothetic approach.

Future research might also include a performance measure after a period of extended home learning to investigate the association between profile membership and actual learning. Because of considerable variation in the duration and extent of remote schooling and the ratio between classroom instruction and learning at home between schools and grade levels as well as large variation between teachers on a more general level, relating performance differences to differences in profile membership is not trivial. Large-scale national and international assessments that evaluate student performance relative to certain standards and allow for comparisons of cohorts over time, however, could be linked to student data providing information on profile membership.

\section{Practical implications}

Although bearing in mind the slight overrepresentation of students from the highest secondary school track, this study still provides a quite positive perspective on students' resources in the face of learning mathematics from home. Students often reported values above the scale mean - or below the scale mean for the negatively coded indirect family support, respectively - on the specific home learning internal and external factors directly related to remote schooling. Exceptions are the unfavorable profile in terms of perceived value and direct family support and the high internal profile also in terms of direct family support. The students felt well supported by their mathematics teachers regarding the provision of material and resources to keep studying even when schools were closed. Although the present data does not allow any causal conclusions, an even more intense contact with the teacher via direct or indirect communication as reflected in the teachersupported profile might also positively affect the students' perceived value and success of mathematics learning from home, particularly in students from less advantaged families and lower school types.

Whereas most of the student groups identified in the latent profile analysis in this study can be considered to possess rather high resources regarding several of the specific home learning conditions, students in the unfavorable profile might be seriously at risk of losing ground when there is an increased necessity for learning from home. These are the students-who are often male and from the lower secondary school track-we should 
specifically attend to (see Agasisti \& Longobardi, 2017). Interventions targeting the materials as well as the structure and guidance provided by teachers during learning from home (e.g., Begeny et al., 2020), on the one hand, and the home learning environment, on the other hand, could be aimed at this group of particularly vulnerable students (see Elliott \& Bachman, 2018). Importantly, educators might assist these students in developing higher internal resources to be more resilient in the face of unfavorable external conditions. Students could hence be supported to improve not only their content knowledge but also their self-regulation and learning strategies. Out-of-school tutoring might be an adequate means here-on condition that families do not have to pay for it (e.g., Heinrich et al., 2014; Rheinheimer et al., 2010).

\section{Conclusion}

When students' prior knowledge, sustained attention, and motivational-affective preconditions are rather impeding mathematics learning than facilitating it, when they come from lower SES families where direct support during learning and indirect support in the form of a distraction-free workplace are less often available, along with less favorable experiences during regular teacher instruction in mathematics and less teacher support during home learning, students also tend to show considerably lower perceived value and success in the face of mathematics learning from home compared to other students. However, this study also suggests that even when general learning internal conditions and the social background of the family are less favorable, family and/or teacher support could substantially improve students' learning motivation during home learning.

Supplementary Information The online version contains supplementary material available at https://doi. org/10.1007/s10212-021-00590-w.

Acknowledgements We want to thank Corina Möller, Ursina Markwalder, and Sebastian Seehars for their support and, in particular, Dilan Hulaj for her great assistance throughout the project.

Funding Open access funding provided by Swiss Federal Institute of Technology Zurich. Sarah I. Hofer was supported by a Jacobs Foundation Research Fellowship (number: 2018 128809).

Data availability All rating scales used in this study are available as supplementary material. The data can be obtained by contacting the first author.

Code availability Not applicable.

\section{Declarations}

Conflict of interest The authors declare no competing interests.

Open Access This article is licensed under a Creative Commons Attribution 4.0 International License, which permits use, sharing, adaptation, distribution and reproduction in any medium or format, as long as you give appropriate credit to the original author(s) and the source, provide a link to the Creative Commons licence, and indicate if changes were made. The images or other third party material in this article are included in the article's Creative Commons licence, unless indicated otherwise in a credit line to the material. If material is not included in the article's Creative Commons licence and your intended use is not permitted by statutory regulation or exceeds the permitted use, you will need to obtain permission directly from the copyright holder. To view a copy of this licence, visit http://creativecommons.org/licenses/by/4.0/. 


\section{References}

Agasisti, T., \& Longobardi, S. (2017). Equality of educational opportunities, schools' characteristics and resilient students: An empirical study of EU-15 countries using OECD-PISA 2009 data. Social Indicators Research, 134(3), 917-953. https://doi.org/10.1007/s11205-016-1464-5

Alexander, K. L., Entwisle, D. R., \& Olson, L. S. (2001). Schools, achievement, and inequality: A seasonal perspective. Educational Evaluation and Policy Analysis, 23(2), 171-191. https://doi.org/10.3102/ 01623737023002171

Almutairi, M. (2021). The effects of parental involvement on student success in middle school. Academic Journal of Research and Scientific Publishing, 2(22), 19-28.

Andrew, A., Cattan, S., Costa Dias, M., Farquharson, C., Kraftman, L., Krutikova, S., Phimister, A., \& Sevilla, A. (2020). Inequalities in children's experiences of home learning during the COVID-19 lockdown in England. Fiscal Studies, 41(3), 653-683. https://doi.org/10.1111/1475-5890.12240

Appleton, J. J., Christenson, S. L., Kim, D., \& Reschly, A. L. (2006). Measuring cognitive and psychological engagement: Validation of the student engagement instrument. Journal of School Psychology, 44(5), 427-445.

Artino, A. R., \& Stephens, J. M. (2006). Learning online: Motivated to self-regulate. Academic Exchange Quarterly, 10(4), 176-182.

Ashcraft, M. H., \& Moore, A. M. (2009). Mathematics anxiety and the affective drop in performance. Journal of Psychoeducational Assessment, 27(3), 197-205. https://doi.org/10.1177/0734282908330580

Asparouhov, T., \& Muthén, B. (2014). Auxiliary variables in mixture modeling: Using the BCH method in Mplus to estimate a distal outcome model and an arbitrary secondary model. Mplus Web Notes, 21(2), 1-22.

Atteberry, A., \& McEachin, A. (2019). School's out: The role of summers in understanding achievement disparities. American Educational Research Journal. https://doi.org/10.26300/2MAM-BP02

Axelrod, M. I., Zhe, E. J., Haugen, K. A., \& Klein, J. A. (2009). Self-management of on-task homework behavior: A promising strategy for adolescents with attention and behavior problems. School Psychology Review, 38(3), 325-333.

Bacci, S., Pandolfi, S., \& Pennoni, F. (2014). A comparison of some criteria for states selection in the latent Markov model for longitudinal data. Advances in Data Analysis and Classification, 8(2), 125-145.

Bakk, Z., \& Vermunt, J. K. (2016). Robustness of stepwise latent class modeling with continuous distal outcomes. Forthcoming in Structural Equation Modeling: A Multidisciplinary Journal., 23(1), 20-31. https://doi.org/10.1080/10705511.2014.955104

Bansak, C., \& Starr, M. (2021). Covid-19 shocks to education supply: How 200,000 U.S. households dealt with the sudden shift to distance learning. Review of Economics of the Household, 19, 63-90. https:// doi.org/10.1007/s11150-020-09540-9

Barkatsas, A. T., Kasimatis, K., \& Gialamas, V. (2009). Learning secondary mathematics with technology: Exploring the complex interrelationship between students' attitudes, engagement, gender and achievement. Computers \& Education, 52(3), 562-570. https://doi.org/10.1016/j.compedu.2008.11.001

Baticulon, R. E., Sy, J. J., Alberto, N. R. I., Baron, M. B. C., Mabulay, R. E. C., Rizada, L. G. T., Tiu, C. J. S., Clarion, C. A., \& Reyes, J. C. B. (2021). Barriers to online learning in the time of COVID-19: A national survey of medical students in the Philippines. Medical Science Educator, 1-12https://doi. org/10.1007/s40670-021-01231-z

Begeny, J. C., Codding, R. S., Wang, J., Hida, R. M., Patterson, S. L., Kessler, S., Fields-Turner, F., \& Ramos, K. A. (2020). An analysis of motivation strategies used within the small-group Accelerating Mathematics Performance through Practice Strategies (AMPPS-SG) program. Psychology in the Schools, 57(4), 540-555. https://doi.org/10.1002/pits.22334

Bergey, B. W., Parrila, R. K., \& Deacon, S. H. (2018). Understanding the academic motivations of students with a history of reading difficulty: An expectancy-value-cost approach. Learning and Individual Differences, 67, 41-52.

Black, A. E., \& Deci, E. L. (2000). The effects of instructors' autonomy support and students' autonomous motivation on learning organic chemistry: A self-determination theory perspective. Science Education, 84(6), 740-756. https://doi.org/10.1002/1098-237X(200011)84:6\%3c740::AID-SCE4\%3e3.0.CO;2-3

Blotenberg, I., \& Schmidt-Atzert, L. (2019). Towards a process model of sustained attention tests. Journal of Intelligence, 7(1), 3. https://doi.org/10.3390/jintelligence 7010003

Broadbent, J. (2017). Comparing online and blended learner's self-regulated learning strategies and academic performance. The Internet and Higher Education, 33, 24-32. https://doi.org/10.1016/j.iheduc. 2017.01.004

Broadbent, J., \& Poon, W. L. (2015). Self-regulated learning strategies \& academic achievement in online higher education learning environments: A systematic review. The Internet and Higher Education, 27, 1-13. https://doi.org/10.1016/j.iheduc.2015.04.007 
Brühwiler, C., \& Blatchford, P. (2011). Effects of class size and adaptive teaching competency on classroom processes and academic outcome. Learning and Instruction, 21(1), 95-108.

Bryan, T., Burstein, K., \& Bryan, J. (2001). Students with learning disabilities: Homework problems and promising practices. Educational Psychologist, 36(3), 167-180.

Coley, R. L., Kruzik, C., \& Votruba-Drzal, E. (2020). Do family investments explain growing socioeconomic disparities in children's reading, math, and science achievement during school versus summer months? Journal of Educational Psychology, 112(6), 1183-1196. https://doi.org/10.1037/edu0000427

Cooper, H., Nye, B., Charlton, K., Lindsay, J., \& Greathouse, S. (1996). The effects of summer vacation on achievement test scores: A narrative and meta-analytic review. Review of Educational Research, 66(3), 227-268. https://doi.org/10.3102/00346543066003227

Deci, E. L., \& Ryan, R. M. (2012). Motivation, personality, and development within embedded social contexts: An overview of self-determination theory. In R. M. Ryan (Ed.), Oxford library of psychology. The Oxford handbook of human motivation (pp. 85-107). Oxford University Press.

Ditton, H., \& Maaz, K. (2011). Sozioökonomischer Status und soziale Ungleichheit [Socio-economic status and social inequality]. In H. Reinders, H. Ditton, C. Gräsel, \& B. Gniewosz (Eds), Empirische Bildungsforschung (pp. 193-208). VS Verlag für Sozialwissenschaften. https://doi. org/10.1007/978-3-531-93021-3_17

Dochy, F. (1994). Prior knowledge and learning. In T. Husen \& T. N. Postlethwaite (Eds.), The International Encyclopedia of Education (2nd ed., pp. 4698-4702). Pergamon Press.

Dowker, A., Sarkar, A., \& Looi, C. Y. (2016). Mathematics anxiety: What have we learned in 60 years? Frontiers in Psychology, 7, 508. https://doi.org/10.3389/fpsyg.2016.00508

Eccles, J. S., Adler, T. F., Futterman, R., Goff, S. B., Kaczala, C. M., Meece, J. L., \& Midgley, C. (1983). Expectancies, values, and academic behaviors. In J. T. Spence (Ed.), Expectancies, values, and academic behaviors (pp. 75-146). Freeman.

Eccles, J. S., \& Wigfield, A. (1995). In the mind of the achiever: The structure of adolescents' academic achievement related-beliefs and self-perceptions. Personality and Social Psychology Bulletin, 21, 215-225.

Eccles, J. S., \& Wigfield, A. (2002). Motivational beliefs, values, and goals. Annual Review of Psychology, 53, 109-132. https://doi.org/10.1146/annurev.psych.53.100901.135153

Eickelmann, B., \& Drossel, K. (2020). Schule auf Distanz. Perspektiven und Empfehlungen für den neuen Schulalltag. Eine repräsentative Befragung von Lehrkräften in Deutschland. Vodafone Stiftung.

Elliott, L., \& Bachman, H. J. (2018). SES disparities in early math abilities: The contributions of parents' math cognitions, practices to support math, and math talk. Developmental Review, 49, 1-15. https://doi.org/10.1016/j.dr.2018.08.001

Engzell, P., Frey, A., \& Verhagen, M. D. (2021). Learning loss due to school closures during the COVID-19 pandemic. Proceedings of the National Academy of Sciences, 118(17), e2022376118. https://doi.org/10.1073/pnas.2022376118

Fischer, C., Fischer-Ontrup, C., \& Schuster, C. (2020). Individuelle Förderung und selbstreguliertes Lernen. Bedingungen und Optionen für das Lehren und Lernen in Präsenz und auf Distanz. In D. Fickermann \& B. Edelstein (Eds.), "Langsam vermisse ich die Schule ...". Schule während und nach der Corona-Pandemie (pp. 136-152). Waxmann. https://doi.org/10.31244/9783830992318.08

Flunger, B., Mayer, A., \& Umbach, N. (2019). Beneficial for some or for everyone? Exploring the effects of an autonomy-supportive intervention in the real-life classroom. Journal of Educational Psychology, 111(2), 210-234. https://doi.org/10.1037/edu0000284

Foster, M. A., Lambert, R., Abbott-Shim, M., McCarty, F., \& Franze, S. (2005). A model of home learning environment and social risk factors in relation to children's emergent literacy and social outcomes. Early Childhood Research Quarterly, 20(1), 13-36. https://doi.org/10.1016/j.ecresq.2005.01.006

Fredricks, J. A., Blumenfeld, P. C., \& Paris, A. H. (2004). School engagement: Potential of the concept, state of the evidence. Review of Educational Research, 74(1), 59-109. https://doi.org/10.3102/00346 543074001059

Fredricks, J. A., \& McColskey, W. (2012). The measurement of student engagement: A comparative analysis of various methods and student self-report instruments. In S. L. Christenson, A. L. Reschly, \& C. Wylie (Eds.), Handbook of research on student engagement (pp. 763-782). Springer. https://doi.org/10.1007/978-1-4614-2018-7_37

Froiland, J. M. (2021). A comprehensive model of preschool through high school parent involvement with emphasis on the psychological facets. School Psychology International, 42(2), 103-131. https://doi.org/10.1177/0143034320981393

Froiland, J. M., Davison, M. L., \& Worrell, F. C. (2016). Aloha teachers: Teacher autonomy support promotes native Hawaiian and Pacific Islander students' motivation, school belonging, course-taking and math achievement. Social Psychology of Education, 19(4), 879-894. https://doi.org/10.1007/ s11218-016-9355-9 
Fung, F., Tan, C. Y., \& Chen, G. (2018). Student engagement and mathematics achievement: Unraveling main and interactive effects. Psychology in the Schools, 55(7), 815-831. https://doi.org/10.1002/pits.22139

Ganzeboom, H., \& Treimann, D. (1996). Internationally comparable measures of occupational status for the 1988 International Standard Classification of Occupations. Social Science Research, 25, 201-239.

Geiser, C. (2011). Data analysis with Mplus. Guilford Press.

Gibson, W. A. (1959). Three multivariate models: Factor analysis, latent structure analysis, and latent profile analysis. Psychometrika, 24(3), 229-252. https://doi.org/10.1007/BF02289845

Gollwitzer, M. (2012). Latent-class-analysis. In H. Moosbrugger, \& A. Kelava (Eds.), Testtheorie und Fragebogenkonstruktion (pp. 295-323). Springer Retrieved from http://link.springer.com/chapter/10. 1007/2F978-3-642-20072-4_12. Accessed Mar 2021.

Gonida, E. N., \& Cortina, K. S. (2014). Parental involvement in homework: Relations with parent and student achievement-related motivational beliefs and achievement. British Journal of Educational Psychology, 84(3), 376-396.

Götz, L., Lingel, K., \& Schneider, W. (2013). DEMAT 6+. Deutscher Mathematiktest für sechste Klassen [German mathematics test for grade 6]. Hogrefe.

Grätz, M., \& Lipps, O. (2021). Large loss in studying time during the closure of schools in Switzerland in 2020. Research in Social Stratification and Mobility, 71, 100554. https://doi.org/10.1016/j.rssm.2020.100554

Gutiérrez, M., Sancho, P., Galiana, L., \& Tomás, J. M. (2018). Autonomy support, psychological needs satisfaction, school engagement and academic success: A mediation model. Universitas Psychologica, 17(5), 1-12. https://doi.org/10.11144/Javeriana.upsy17-5.aspn

Hannula, M. S., Di Martino, P., Pantziara, M., Zhang, Q., Morselli, F., Heyd-Metzuyanim, E., ... \& A Goldin, G. (2016). Attitudes, beliefs, motivation and identity in mathematics education: An overview of the field and future directions. Springer Nature.

Heinrich, C. J., Burch, P., Good, A., Acosta, R., Cheng, H., Dillender, M., Kirshbaum, C., Nisar, H., \& Stewart, M. (2014). Improving the implementation and effectiveness of out-of-school-time tutoring. Journal of Policy Analysis and Management, 33(2), 471-494. https://doi.org/10.1002/pam.21745

Helmke, A., \& Weinert, F. E. (1997). Bedingungsfaktoren schulischer Leistungen. Max-Planck-Inst. für Psychologische Forschung.

Hembree, R. (1990). The nature, effects, and relief of anxiety mathematics. Journal for Research in Mathematics Education, 21(1), 33-46. https://doi.org/10.2307/749455

Hernán, M., Hernández-Díaz, S., \& Robins, J. (2004). A structural approach to selection bias. Epidemiology, 15(5), 615-625. Retrieved February 12, 2021, from http://www.jstor.org/stable/20485961

Hickendorff, M., Edelsbrunner, P. A., Schneider, M., Trezise, K., \& McMullen, J. (2017). Informative tools for characterizing individual differences in learning: Latent class, latent profile, and latent transition analyses. Learning and Individual Differences, 66, 4-15. https://doi.org/10.1016/j.lindif.2017.11.001

Hiebert, J., \& Grouws, D. A. (2007). The effects of classroom mathematics teaching on students' learning. Second Handbook of Research on Mathematics Teaching and Learning, 1, 371-404.

Hidi, S., \& Renninger, K. A. (2006). The four-phase model of interest development. Educational Psychologist, 41(2), 111-127. https://doi.org/10.1207/s15326985ep4102_4

Hofer, S., Nistor, N., \& Scheibenzuber, C. (2021). Online teaching and learning in higher education: Lessons learned in crisis situations. Computers in Human Behavior, 106789.

Hofer, S. I., Reinhold, F., Loch, F., \& Vogel-Heuser, B. (2020). Engineering Students' Thinking About Technical Systems: An Ontological Categories Approach. Frontiers in Education, 5. https://doi.org/ $10.3389 /$ feduc. 2020.00066

Hofer, S. I., \& Stern, E. (2016). Underachievement in physics: When intelligent girls fail. Learning and Individual Differences, 51, 119-131.

von Hippel, P., \& Hamrock, C. (2019). Do test score gaps grow before, during, or between the school years? Measurement artifacts and what we can know in spite of them. Sociological Science, 6, 43-80. https:// doi.org/10.15195/v6.a3

Huber, S. G., \& Helm, C. (2020). Lernen in Zeiten der Corona-Pandemie. In D. Fickermann \& B. Edelstein (Eds.), „Langsam vermisse ich die Schule ... “ (pp. 37-60). Waxmann. https://doi.org/10.31244/9783830992318.02

Jones, J. I. (2014). An overview of employment and wages in science, technology, engineering, and math (STEM) groups. Beyond the Numbers: Employment and Unemployment, 3(8), 1-4. http://www.bls. gov/opub/btn/volume-3/an-overview-of-employment.htm. Accessed Mar 2021.

Koch, M., Möller, C., Spinath, F. M. (under review). Are you Swiping, or Just Marking? Development and Evaluation of the Attention Swiping Task.

Köller, O., Fleckenstein, J., Guill, K., \& Meyer, J. (2020). Pädagogische und didaktische Anforderungen an die häusliche Aufgabenbearbeitung. In D. Fickermann \& B. Edelstein (Eds.), „Langsam vermisse ich die Schule ... “ (pp. 163-174). Waxmann. https://doi.org/10.31244/9783830992318.10 
Köller, O., Trautwein, U., Luedtke, O., \& Baumert, J. (2006). On the interplay of academic achievement, self-concept, and interest in upper secondary schools. Zeitschrift Für Pädagogische Psychologie, 20(1-2), 27-39. https://doi.org/10.1024/1010-0652.20.12.27

Kosovich, J. J., Flake, J. K., \& Hulleman, C. S. (2017). Short-term motivation trajectories: A parallel process model of expectancy-value. Contemporary Educational Psychology, 49, 130-139.

Kuhfeld, M. (2019). Surprising new evidence on summer learning loss. Phi Delta Kappan, 101(1), 25-29. https://doi.org/10.1177/0031721719871560

Kuhfeld, M., Soland, J., Tarasawa, B., Johnson, A., Ruzek, E., \& Liu, J. (2020). Projecting the potential impact of COVID-19 school closures on academic achievement. Educational Researcher, 49(8), 549565. https://doi.org/10.3102/0013189X20965918

Lazarsfeld, P. F., \& Henry, N.W. (1968). Latent structure analysis. Houghton Mifflin.

Lohr, A., Stadler, M., Schultz-Pernice, F., Chernikova, O., Sailer, M., Fischer, F., \& Sailer, M. (2021). On powerpointers, clickerers, and digital pros: Investigating the initiation of digital learning activities by teachers in higher education. Computers in Human Behavior, 119, 106715.

Ma, X. (1999). A meta-analysis of the relationship between anxiety toward mathematics and achievement in mathematics. Journal for Research in Mathematics Education, 30(5), 520-540. https://doi.org/10. 2307/749772

Maguire, E. A., Frith, C. D., \& Morris, R. G. M. (1999). The functional neuroanatomy of comprehension and memory: The importance of prior knowledge. Brain, 122(10), 1839-1850.

Marsh, H. W., Lüdtke, O., Trautwein, U., \& Morin, A. J. S. (2009). Classical latent profile analysis of academic self-concept dimensions: Synergy of person- and variable-centered approaches to theoretical models of self-concept. Structural Equation Modeling: A Multidisciplinary Journal, 16(2), 191-225. https://doi.org/10.1080/10705510902751010

Marsh, H. W., \& Martin, A. J. (2011). Academic self-concept and academic achievement: Relations and causal ordering. British Journal of Educational Psychology, 81(1), 59-77. https://doi.org/10.1348/ $000709910 \times 503501$

Marsh, H. W., Xu, M., \& Martin, A. J. (2012). Self-concept: A synergy of theory, method, and application. In K. R. Harris, S. Graham, T. Urdan, C. B. McCormick, G. M. Sinatra, \& J. Sweller (Eds.), APA educational psychology handbook. Theories, constructs, and critical issues (Vol 1, pp. 427-458). American Psychological Association. https://doi.org/10.1037/13273-015

Möller, J., Retelsdorf, J., Köller, O., \& Marsh, H. W. (2011). The reciprocal internal/external frame of reference model: An integration of models of relations between academic achievement and self-concept. American Educational Research Journal, 48(6), 1315-1346. https://doi.org/10.3102/0002831211419649

Müller, K., \& Ehmke, T. (2013). Soziale Herkunft als Bedingung der Kompetenzentwicklung. In M. Prenzel, C. Sälzer, E. Klieme, \& O. Köller (Eds.), PISA 2012. Fortschritte und Herausforderungen in Deutschland (pp. 245-274). Waxmann.

Muthén, L. K., \& Muthén, B. O. (1998-2017). Mplus User’s Guide (8th ed.). Muthén \& Muthén.

National Center for Education Statistics (2017). National Assessment of Educational Progress Mathematics. https://www.nationsreportcard.gov/math_2017. Accessed Mar 2021.

Nylund, K. L., Asparouhov, T., \& Muthén, B. O. (2007). Deciding on the number of classes in latent class analysis and growth mixture modeling: A Monte Carlo simulation study. Structural Equation Modeling, 14(4), 535-569. https://doi.org/10.1080/10705510701575396

Oakes, L. M., Kannass, K. N., \& Shaddy, D. J. (2002). Developmental changes in endogenous control of attention: The role of target familiarity on infants' distraction latency. Child Development, 73(6), 1644-1655.

OECD. (2016). PISA 2015 results: Excellence and equity in education (Vol. OECD Publishing. https://doi. org/10.1787/9789264266490-en

OECD (2019). PISA 2018 results: Combined executive summaries. OECD Publishing.

Ortiz, P. A. (2020). Teaching in the time of COVID-19. Biochemistry and Molecular Biology Education, 48(3), 201. https://doi.org/10.1002/bmb.21348

Panadero, E., \& Alonso Tapia, J. (2014). How do students self-regulate? Review of Zimmerman's cyclical model of self-regulated learning. Anales De Psicologia, 30(2), 450-462.

Pekrun, R., Vom Hofe, R., Blum, W., Götz, T., Wartha, S., \& Jullien, S. (2006). Projekt zur Analyse der Leistungsentwicklung in Mathematik (PALMA). In M. Prenzel \& L. Allolio-Näcke (Eds.), Untersuchungen zur Bildungsqualität von Schule. Abschlussbericht des DFG-Schwerpunktprogramms (pp. 21-53). Waxmann.

Prenzel, M., \& Drechsel, B. (1996). Ein Jahr kaufmännische Erstausbildung: Veränderungen in Lernmotivation und Interesse [One year of initial business management training: Changes in learning motivation and interest]. Unterrichtswissenschaft, 24, 217-234. 
Quinn, D. M., Cooc, N., McIntyre, J., \& Gomez, C. J. (2016). Seasonal dynamics of academic achievement inequality by socioeconomic status and race/ethnicity. Educational Researcher, 45(8), 443-453. https://doi.org/10.3102/0013189X16677965

Reinhold, F., Hofer, S. I., Hoch, S., Werner, B., Richter-Gebert, J., \& Reiss, K. (2020a). Digital support principles for sustained mathematics learning in disadvantaged students. PloS one, 15(10), e0240609.

Reinhold, F., Hoch, S., Werner, B., Richter-Gebert, J., \& Reiss, K. (2020b). Learning fractions with and without educational technology: What matters for high-achieving and low achieving students?. Learning and Instruction, 65, 101264.

Reinhold, F., Hoch, S., Schiepe-Tiska, A., Strohmaier, A. R., \& Reiss, K. (2021). Motivational and Emotional Orientation, Engagement, and Achievement in Mathematics. A Case Study With One SixthGrade Classroom Working With an Electronic Textbook on Fractions. Frontiers in Education, 6. https://doi.org/10.3389/feduc.2021.588472

Reinhold, F., Reiss, K., Diedrich, J., Hofer, S. I., \& Heinze, A., et al. (2019). Mathematische Kompetenz in PISA 2018: Aktueller Stand und Entwicklung. In K. Reiss (Ed.), PISA 2018 (pp. 187-209). Waxmann.

Rheinheimer, D. C., Grace-Odeleye, B., Francois, G. E., \& Kusorgbor, C. (2010). Tutoring: A support strategy for at-risk students. Learning Assistance Review, 15(1), 23-34. https://eric.ed.gov/?id=ej886384. Accessed Mar 2021.

Richardson, F. C., \& Suinn, R. M. (1972). The mathematics anxiety rating scale: Psychometric data. Journal of Counseling Psychology, 19(6), 551. https://doi.org/10.1037/h0033456

Romero, M., \& Barberà, E. (2011). Quality of e-learners' time and learning performance beyond quantitative time-on-task. The International Review of Research in Open and Distributed Learning, 12(5), 125-137. https://doi.org/10.19173/irrodl.v12i5.999

Ryan, R. M., \& Deci, E. L. (2000). Self-determination theory and the facilitation of intrinsic motivation, social development, and well-being. American Psychologist, 55(1), 68-78. https://doi.org/10.1037/ 0003-066X.55.1.68

Ryan, R. M., \& Deci, E. L. (2020). Intrinsic and extrinsic motivation from a self-determination theory perspective: Definitions, theory, practices, and future directions. Contemporary Educational Psychology, 61, 101860. https://doi.org/10.1016/j.cedpsych.2020.101860

Ryan, R. M., \& Grolnick, W. S. (1986). Origins and pawns in the classroom: Self-report and projective assessments of individual differences in children's perceptions. Journal of Personality and Social Psychology, 50(3), 550-558. https://doi.org/10.1037/0022-3514.50.3.550

Sälzer, C., Reiss, K., Schiepe-Tiska, A., Prenzel, M., \& Heinze, A. (2013). Zwischen Grundlagenwissen und Anwendungsbezug: Mathematische Kompetenz im internationalen Vergleich [Between basic knowledge and application: Mathematical competency compared to international standards]. In $\mathbf{M}$. Prenzel, C. Sälzer, E. Klieme, \& O. Köller (Eds.), PISA 2012: Fortschritte und Herausforderungen in Deutschland (pp. 47-98). Waxmann.

Schult, J., Mahler, N., Fauth, B., \& Lindner, M. A. (2021). Did students learn less during the COVID-19 pandemic? Reading and Mathematics Competencies Before and After the First Pandemic Wave [Preprint]. PsyArXiv. https://doi.org/10.31234/osf.io/pqtgf

Schwartz, D. L., Sears, D., \& Chang, J. (2007). Reconsidering prior knowledge. Thinking with data, 319-344.

Schwarz, G. (1978). Estimating the dimension of a model. The Annals of Statistics, 6(2), 461-464.

Schweizer, K., \& Moosbrugger, H. (2004). Attention and working memory as predictors of intelligence. Intelligence, 32(4), 329-347.

Sclove, S. L. (1987). Application of model-selection criteria to some problems in multivariate analysis. Psychometrika, 52(3), 333-343.

Seidel, T. (2007). The role of student characteristics in studying micro teaching-learning environments. Learning Environments Research, 9(3), 253-271. https://doi.org/10.1007/s10984-006-9012-x

Skinner, E. A., \& Belmont, M. J. (1993). Motivation in the classroom: Reciprocal effects of teacher behavior and student engagement across the school year. Journal of Educational Psychology, 85(4), 571-581. https://doi.org/10.1037/0022-0663.85.4.571

Skinner, E. A., Furrer, C., Marchand, G., \& Kindermann, T. (2008). Engagement and disaffection in the classroom: Part of a larger motivational dynamic? Journal of Educational Psychology, 100(4), 765. https://doi.org/10.1037/a0012840

Smart, R. G. (1966). Subject selection bias in psychological research. Canadian Psychologist/Psychologie canadienne, 7a(2), 115-121. https://doi.org/10.1037/h0083096

Soria, K. M., Horgos, B., \& McAndrew, M. (2020). Obstacles that may result in delayed degrees for graduate and professional students during the COVID-19 pandemic. https://escholarship.org/uc/item/8d46b 49s. Accessed Mar 2021. 
Spearman, J., \& Watt, H. M. G. (2013). Perception shapes experience: The influence of actual and perceived classroom environment dimensions on girls' motivations for science. Learning Environments Research, 16(2), 217-238. https://doi.org/10.1007/s10984-013-9129-7

Steinmayr, R., Ziegler, M., \& Träuble, B. (2010). Do intelligence and sustained attention interact in predicting academic achievement? Learning and Individual Differences, 20(1), 14-18.

Stern, E. \& Hofer, S. I. (2014). Wer gehört aufs Gymnasium? Intelligenzforschung und Schullaufbahnentscheidungen. In Wyss, E. (Ed.). Von der Krippe zum Gymnasium. Bildung und Erziehung im 21. Jahrhundert (S. 41-54). Einheim und Basel: Beltz Juventa.

Stone, J. R., III., Alfeld, C., \& Pearson, D. (2008). Rigor and relevance: Enhancing high school students' math skills through career and technical education. American Educational Research Journal, 45(3), 767-795. https://doi.org/10.3102/0002831208317460

Stroet, K., Opdenakker, M.-C., \& Minnaert, A. (2013). Effects of need supportive teaching on early adolescents' motivation and engagement: A review of the literature. Educational Research Review, 9, 65-87. https://doi.org/10.1016/j.edurev.2012.11.003

Tofighi, D., \& Enders, C. K. (2007). Identifying the correct number of classes in growth mixture models. In G. R. Hancock \& K. M. Samuelsen (Eds.), Advances in latent variable mixture models (pp. 317-341). Information Age Publishing.

Valero, P., Graven, M., Jurdak, M., Martin, D., Meaney, T., \& Penteado, M. (2015). Socioeconomic influence on mathematical achievement: What is visible and what is neglected. In S. J. Cho (Ed.). The Proceedings of the 12th International Congress on Mathematical Education (pp. 285-301). Springer.

Vermunt, J. K., \& Magidson, J. (2002). Latent class cluster analysis. In J. Hagenaars \& A. McCutcheon (Eds.), Applied latent class analysis (pp. 89-106). Cambridge University Press.

Vroom, V. H. (1964). Work and motivation. Wiley and Sons.

Wang, M. T., Fredricks, J. A., Ye, F., Hofkens, T. L., \& Linn, J. S. (2016). The math and science engagement scales: Scale development, validation, and psychometric properties. Learning and Instruction, 43, 16-26.

Wei, D., Zhang, D., He, J., \& Bobis, J. (2019). The impact of perceived teachers' autonomy support on students' mathematics achievement: Evidences based on latent growth curve modelling. European Journal of Psychology of Education, 35, 703-725. https://doi.org/10.1007/s10212-019-00437-5

Wigfield, A., \& Eccles, J. S. (2000). Expectancy-value theory of achievement motivation. Contemporary Educational Psychology, 25(1), 68-81. https://doi.org/10.1006/ceps.1999.1015

Wößmann, L., Freundl, V., Grewenig, E., Lergetporer, P., Werner, K., \& Zierow, L. (2020). Bildung in der Coronakrise: Wie haben die Schulkinder die Zeit der Schulschließungen verbracht, und welche Bildungsmaßnahmen befürworten die Deutschen? ifo Schnelldienst, 73(09), 25-39. http://hdl.handle.net/ 10419/225170. Accessed Mar 2021.

Yang, C.-C. (2006). Evaluating latent class analysis models in qualitative phenotype identification. Computational Statistics and Data Analysis, 50(4), 1090-1104. https://doi.org/10.1016/j.csda.2004.11.004

Yang, C.-C., \& Yang, C.-C. (2007). Separating latent classes by information criteria. Journal of Classification, 24(2), 183-203. https://doi.org/10.1007/s00357-007-0010-1

Zady, M. F., \& Portes, P. R. (2001). When low-SES parents cannot assist their children in solving science problems. Journal of Education for Students Placed at Risk (JESPAR), 6(3), 215-229. https://doi.org/ 10.1207/S15327671ESPR0603_4

Sarah I. Hofer. Chair for Learning and Technology, ETH Zurich, Weinbergstrasse 43, 8092 Zurich, Switzerland. sarah.hofer@gess.ethz.ch.

Current themes of research:

Learning with digital media, effective instructional methods, individual differences in learning and school success, gender and STEM, STEM education.

Most relevant publications in the field of Psychology of Education:

Hofer, S. I., Nistor, N., \& Scheibenzuber, C. (2021). Online teaching and learning in higher education: Lessons learned in crisis situations. Computers in Human Behavior, 121, https://doi.org/10.1016/j.chb. 2021.106789

Hofer, S. I., Holzberger, D., \& Reiss, K. (2020). Evaluating school inspection effectiveness: A systematic research synthesis on 30 years of international research. Studies in Educational Evaluation. 65, https://doi.org/10.1016/j.stueduc.2020.100864

Hofer, S. I., Reinhold, F., Loch, F., \& Vogel-Heuser, B. (2020). Engineering Students' Thinking About Technical Systems: An Ontological Categories Approach. Front. Educ., 5(66). https://doi.org/10.3389/ feduc. 2020.00066

Hofer, S. I., Schumacher, R., Rubin, H., \& Stern, E. (2018). Enhancing physics learning with cognitively activating instruction: A classroom intervention study. Journal of Educational Psychology, 110(8), 1175-1191. https://doi.org/10.1037/edu0000266 
Hofer, S. I., Schumacher, R., \& Rubin, H. (2017). The Test of basic Mechanics Conceptual Understanding (bMCU): Using Rasch analysis to develop and evaluate an efficient multiple-choice test on Newton's mechanics. International Journal of STEM Education, 4(18). https://doi.org/10.1186/ s40594-017-0080-5

Hofer, S. I. \& Stern, E. (2016). Underachievement in physics: When intelligent girls fail. Learning and Individual Differences, 51, 119-131. https://doi.org/10.1016/j.lindif.2016.08.006

Hofer, S. I. (2015). Studying gender bias in physics grading: The role of teaching experience and country. International Journal of Science Education, 37(17), 2879-2905. https://doi.org/10.1080/09500 693.2015.1114190

Frank Reinhold. Institute for Mathematics Education Freiburg (IMBF), University of Education Freiburg, Kunzenweg 21, 79,117 Freiburg, Germany. frank.reinhold@ph-freiburg.de.

Current themes of research:

Psychology of mathematics education, educational technology, motivational and emotional orientations, student engagement, process data analysis.

Most relevant publications in the field of Psychology of Education:

Reinhold, F., Hoch, S., Werner, B., Richter-Gebert, J. \& Reiss, K. (2020). Learning Fractions with and without Educational Technology: What Matters for High-Achieving and Low-Achieving Students? Learning and Instruction, 65, 101264. 10.1016/ j.learninstruc.2019.101264

Reinhold, F., Strohmaier, A., Hoch, S., Reiss, K., Böheim, R. \& Seidel, T. (2020). Process data from electronic textbooks indicate students' classroom engagement. Learning and Individual Differences, 83-84, 101934. https://doi.org/10.1016/j.lindif.2020.101934

Hillmayr, D., Ziernwald, L., Reinhold, F., Hofer, S. I. \& Reiss, K. M. (2020). The potential of digital tools to enhance mathematics and science learning in secondary schools: A context-specific metaanalysis. Computers \& Education, 153, 103897. https://doi.org/10.1016/j.compedu.2020.103897 Reinhold, F., Hoch, S., Schiepe-Tiska, A., Strohmaier, A. \& Reiss, K. (2021). Motivational and emotional orientation, engagement, and achievement in mathematics. A case study with one sixthgrade classroom working with an electronic textbook on fractions. Frontiers in Education, 6, 588472. https://doi.org/10.3389/feduc.2021.588472

Reinhold, F., Schons, C., Scheuerer, S., Gritzmann, P., Richter-Gebert, J. \& Reiss, K. (2021). Students' coping with the self-regulatory demand of crisis-driven digitalization in university mathematics instruction: do motivational and emotional orientations make a difference? Computers in Human Behavior, 120, 106732. https://doi.org/10.1016/j.chb.2021.106732

Marco Koch. Individual Differences \& Psychodiagnostics, Saarland University, Campus A1 3, 66,123 Saarbrücken, Germany. marco.koch@uni-saarland.de.

Current themes of research:

Computer-based testing, improvement of psychological measurement instruments, intelligence, sustained attention.

Most relevant publications in the field of Psychology of Education:

Becker, N., Koch, M., Schult, J., \& Spinath, F. M. (2019). Setting Doesn't Matter Much: A MetaAnalytic Comparison of the Results of Intelligence Tests Obtained in Group and Individual Settings. European Journal of Psychological Assessment, 35, 309-316. https://doi.org/10.1027/1015-5759/ a000402

Krautter, K., Lehmann, J., Kleinort, E., Koch, M., Spinath, F. M., \& Becker, N. (2021). Test Preparation in Figural Matrices Tests: Focus on the Difficult Rules. Frontiers in Psychology, 12. Levacher, J., Koch, M., Hissbach, J., Spinath, F. M., \& Becker, N. (2021). You Can Play the Game Without Knowing the Rules - But You're Better Off Knowing Them: The Influence of Rule Knowledge on Figural Matrices Tests. European Journal of Psychological Assessment, 1-9. https://doi.org/10. 1027/1015-5759/a000637

Thissen, A., Koch, M., Becker, N., \& Spinath, F. M. (2018). Construct Your Own Response: The Cube Construction Task as a Novel Format for the Assessment of Spatial Ability. European Journal of Psychological Assessment, 34, 304-311. https://doi.org/10.1027/1015-5759/a000342

Publisher's Note Springer Nature remains neutral with regard to jurisdictional claims in published maps and institutional affiliations. 